\title{
Asynchronous instability of the North American-Arctic and Greenland ice sheets during the last deglaciation
}

Rebecca Jackson ${ }^{1 *}$, Anders E. Carlson ${ }^{2}$, Claude Hillaire-Marcel ${ }^{3}$, Lukas Wacker ${ }^{4}$, Christoph Vogt ${ }^{5}$, Michal Kucera ${ }^{1}$

${ }^{1}$ MARUM - Centre for Marine Environmental Sciences, Leobener Straße, Bremen 28203, Germany (mkucera@marum.de)

${ }^{2}$ College of Earth, Ocean, and Atmospheric Sciences, Oregon State University, Corvallis, OR 97331, USA (acarlson@coas.oregonstate.edu)

${ }^{3}$ GEOTOP, Université du Québec à Montréal, CP 8888, succ. Centre-Ville, Montréal, Québec, H3C 3P8, Canada (hillaire-marcel.claude@uqam.ca)

${ }^{4}$ Laboratory of Ion Beam Physics, ETHZ, Otto-Stern-Weg 5, Zürich, 8093, Switzerland (wacker@phys.ethz.ch)

${ }^{5}$ Zentrallabor für Kristallographie und Angewandte Materialwissenschaften (ZEKAM), Department of Geoscience, Universität Bremen, Klagenfurter Str., Bremen 28359, Germany (cvogt@uni-bremen.de) *Corresponding author: Rebecca Jackson (rjackson@marum.de)

Keywords: Quaternary; Glaciology (inc. paleo-ice sheets); sedimentology - marine cores; Baffin Bay; last deglaciation; ice-sheet retreat; radiocarbon dating; detrital carbonate events 


\section{Abstract}

2 The chronology of deglacial meltwater pulses from the Laurentide Ice Sheet is well documented. 3 However, the deglacial history of the North American-Arctic (north-eastern Laurentide and Innuitian) and western Greenland ice sheets draining into the Labrador Sea via Baffin Bay is less well constrained. Here we present new high-resolution, radiocarbon-dated records from the central Baffin Bay spanning $\sim 17$ to $10 \mathrm{kyr}$ BP and documenting the full deglacial history of Baffin Bay. Sedimentological and geochemical data confirm the presence of two periods of enhanced detrital carbonate delivery, termed Baffin Bay Detrital Carbonate Events (BBDCs). These events are dated to 14.2-13.7 kyr BP and $12.7-11 \mathrm{kyr}$ BP. They are synchronous across Baffin Bay and their mineralogical signature indicates a common source of detrital carbonate from northern Baffin Bay. The first event, BBDC 1, postdates Heinrich Event 1 and the second event BBDC 0 predates the recently revised timing of Heinrich Event 0 . The onset of the BBDC events appears not to be systematically linked to Greenland temperature change as they occur during both interstadial and stadial periods. This indicates that deglaciation of North American-Arctic and western Greenland ice sheets with the associated iceberg and meltwater discharge were decoupled from the dominant North Atlantic climate mode, where iceberg discharge events from the Laurentide Ice Sheet occurred during stadial periods.

\section{Introduction}

The transition from the Last Glacial Maximum to the Holocene was characterised by rapid changes in temperature, ice sheet volume and ocean circulation (Carlson and Clark, 2012; Clark et al., 2012; Shakun and Carlson, 2010). In the Arctic and sub-Arctic regions, this transition is associated with two distinct events of ice sheet instability, known as Heinrich Events 1 and 0 (see a review in Clark et al., 2012). Heinrich Events, massive discharges of icebergs mostly from surges of the Laurentide Ice Sheet (Heinrich, 1988), are well documented in Labrador Sea (Andrews et al., 2012; Pearce et al., 2015; Stoner et al., 1996) and North Atlantic (Bond et al., 1997; Channell et al., 2012; Hemming, 2004) sedimentary records and their timing is well constrained. Heinrich Events are associated with cold stadial conditions in the North Atlantic, but their causal relationship to stadial coolings is unclear (Bond et al., 1993; Broecker, 1994; Marcott et al., 2011). Notwithstanding their exact relationship with 
the regional climate evolution, these events were associated with large meltwater injections into the North Atlantic and as such likely to have had an impact on deep-water formation, especially in the Labrador Sea, thus modulating the global climate evolution of the last deglaciation (McManus et al., 2004; Thornalley et al., 2011). Most climate hypotheses and paleoclimate models assume that deglacial meltwater discharge into the North Atlantic was associated with Heinrich Events sourced from the Hudson Bay. However, there exists a second potential meltwater route, from Baffin Bay (e.g. Simon et al., 2014). Compared to the well-known chronology of late glacial meltwater discharges from the Labrador Dome of the Laurentide Ice Sheet since the Last Glacial Maximum (LGM), meltwater discharges from ice sheets that drain into Baffin Bay are less well documented and still loosely dated: a gap we intend to fill here.

\subsection{Regional setting and previous work}

During the LGM, Baffin Bay was flanked by three major ice sheets that flowed into it: the Greenland Ice Sheet (GIS), north-eastern sector of the Laurentide Ice Sheet (LIS) and the south-eastern sector of the Innuitian Ice Sheet (IIS) (Dyke et al., 2002; England et al., 2006). We will term these as the North American-Arctic and western Greenland ice sheets. These ice sheets expanded into the fjord systems surrounding Baffin Bay and filled marine channels such as the Nares Strait/Smith Sound, and Lancaster and Jones Sound (Figure 1) (Dyke et al., 2002; Li et al., 2011) as well as resulting in the spreading of an ice shelf across the northern Baffin Bay (Marcott et al., 2011). The GIS advanced through Disko Bugt and the Uummannaq Trough as far as the shelf edge on the western Greenland margin (Ó Cofaigh et al., 2013; Ò Cofaigh et al., 2013a).

Baffin Bay has a counter-clockwise oceanic circulation (Tang et al., 2004). The colder East Greenland Current and warmer Irminger Current join to form the West Greenland Current (WGC) that enters Baffin Bay via the Davis Strait and travels north along the west coast of Greenland. Paleoceaongraphic records from the Uummannaq region of the west Greenland shelf suggest the establishment of 'warm' WGC prior to $14 \mathrm{kyr}$ BP (Sheldon et al., 2016). At the head of Baffin Bay the WGC recirculates south, incorporating Arctic waters and forming the Baffin Island Current (BIC). The BIC travels south along Baffin Island, with some recirculation east towards Greenland, while the rest flows into the Labrador Sea via the Davis Strait, forming part of the Labrador Current (Figure 1). 
As well as the direct sources of sediment from the adjacent landmasses and shelves, this ocean current configuration provided a southerly path for iceberg-rafting and meltwater discharge from the North American-Arctic ice sheets (England et al., 2006; Simon et al., 2014), as well as a northerly path from the western GIS and its previously glaciated shelf (Jennings et al., 2014; Ò Cofaigh et al., 2013). In the northern region of Baffin Bay, many of the major paleo-ice streams draining the IIS and north-eastern LIS, such as the Nares Strait/Smith Sound and Lancaster Sound (Figure 1) are flanked by large areas of Palaeozoic limestones and dolostones (Hiscott et al., 1989). This is in contrast to the older Archean Nagssugtoqidian Mobile Belt (NMB) of the central west Greenland coast. Discrete discharge events originating from northern Baffin Bay are hence recorded in marine sedimentary records as layers rich in detrital carbonate, generally ice-rafted southward along the path of the BIC (Andrews et al., 2011). In contrast with the calcite-rich mineralogical signature of detrital carbonate layers originating from the Hudson Strait, ice-rafted detrital carbonate layers found in Baffin Bay are characterised by a calcite/dolomite ratio 0.25:1 (Andrews et al., 2014, 1998, 1995; Simon et al., 2014).

Two BBDC events have been previously identified during the last deglaciation (Aksu and Piper, 1987; Andrews et al., 1998; Hiscott et al., 1989; Simon et al., 2014, 2012). Magnetostratigraphic dating of these records has been recently used to suggest that these events were not in phase with the North Atlantic Heinrich Events (Simon et al., 2014, 2012) but much uncertainty exists in such a paleomagnetic-based chronology, demonstrated by its recent revision (Simon et al., 2016). This uncertainty derives from the ambiguity in tuning noisy curves to a target curve that, in itself, includes dating uncertainty. If periods of iceberg and meltwater discharge from the ice sheets draining into Baffin Bay (i.e. BBDCs) were asynchronous Heinrich Events, this could have implications for the history of meltwater delivery into the Labrador Sea and North Atlantic. Obviously, a robust chronology would allow here for a better evaluation of the relationship between iceberg discharge and deglacial climate change (Bond et al., 1993; Broecker, 1994).

Deep sea sediments in Baffin Bay are affected by poor preservation of biogenic carbonate, particularly during the Holocene (Aksu, 1983), which has so far hindered the construction of a radiocarbon chronology for the deglaciation and thus a robust assessment of the melting history of the 
surrounding ice sheets. Here we present two new deglacial records from Baffin Bay (Figure 1), from sites where a better preservation of benthic and planktonic foraminifera is observed. Better preservation is likely due here to the cored sediment depths near the carbonate compensation depth (CCD), ranging from 600-900 m in Baffin Bay (Aksu, 1983), as compared to deeper cores (> $2000 \mathrm{~m}$ water depth, e.g. Simon et al., 2012). Combined with the use of a new preparation technique for radiocarbon dating of ultra-small samples (Bard et al., 2015; Wacker et al., 2013), we are now in a situation to (i) precisely determine the ages and durations of BBDC events and (ii) set a reliable deglacial chronology of meltwater discharge events from the North American-Arctic and western Greenland ice sheets.

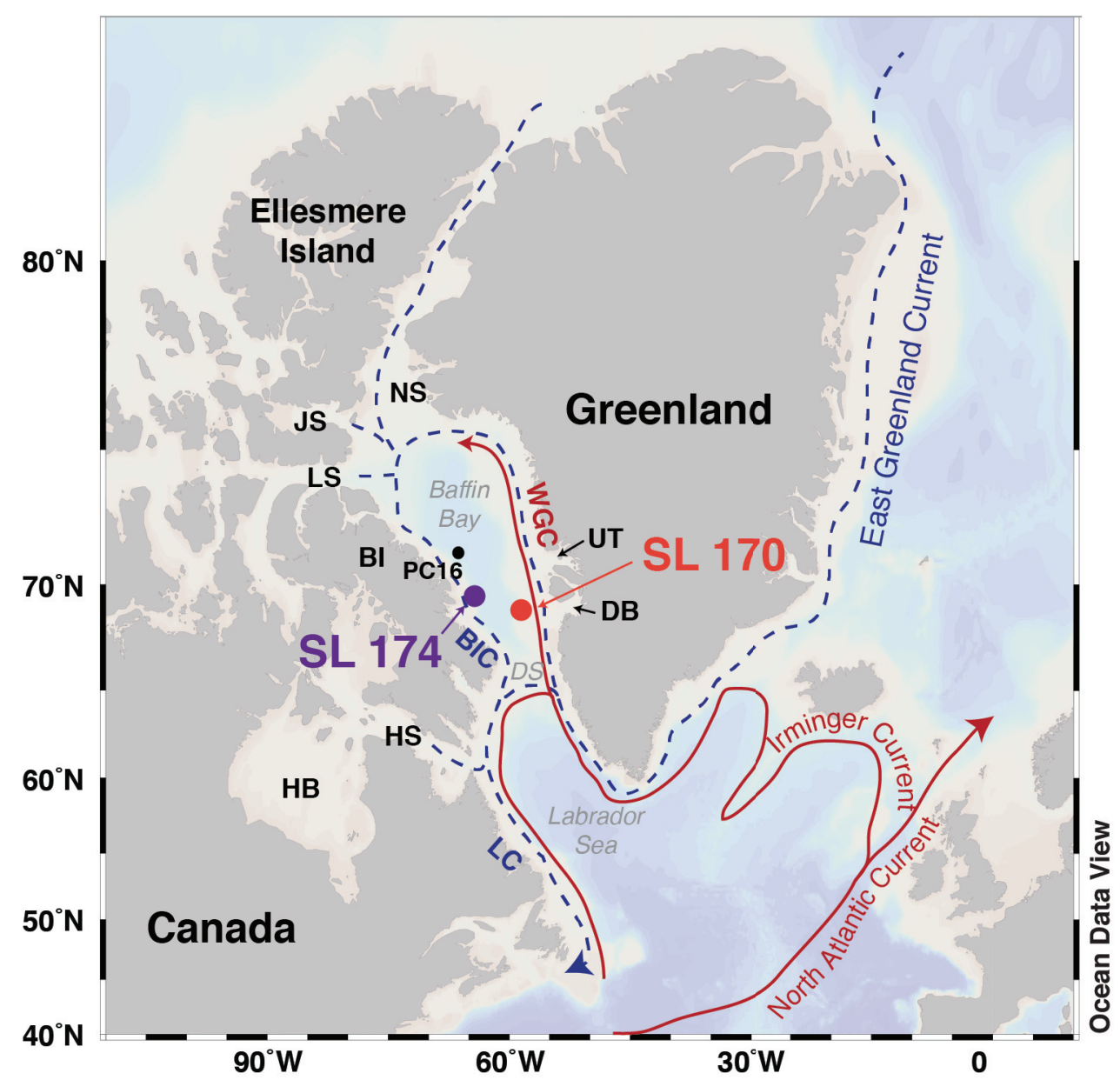

Figure 1. Location of Baffin Bay, surrounding land masses (BI = Baffin Island), 'modern' oceanography and core location used in this study (SL 170 and SL 174). The location of core PC 16 (Simon et al., 2014, 2012) is also shown. Warm currents originating in the North Atlantic are shown by solid red lines (WGC $=$ West Greenland 
Current). Cooler currents of Arctic origin are shown by blue dashed line $(\mathrm{BIC}=$ Baffin Island Current; $\mathrm{LC}=$ Labrador Current). Areas of meltwater/water influx into the Baffin Bay are also shown (DS = Davis Strait; DB = Disko Bugt; UT = Uummannaq Trough; NS = Nares Strait; JS = Jones Sound; LS = Lancaster Sound; HB = Hudson Bay; HS = Hudson Strait).

\section{Methods and Material}

\subsection{Core locations}

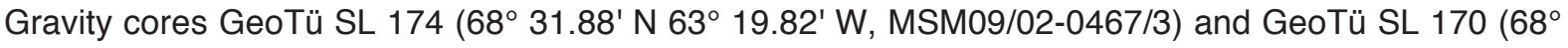
58.15' N 59²3.58' W, MSM09/02-0455/13) were retrieved aboard the RV Maria S. Merian research cruise MSM09/02 (Kucera et al., 2014) in 2008. Cores are herein referred to by number only. SL 174 ( $777.5 \mathrm{~cm}$ in length) was retrieved from $1559 \mathrm{~m}$ water depth off the coast of Baffin Island. SL 170 (683 $\mathrm{cm}$ in length) was retrieved from $1078 \mathrm{~m}$ water depth in the eastern region of Baffin Bay, to the west of Disko Bugt (Figure 1). PARASOUND ${ }^{\mathrm{TM}}$ surveys at the core sites and magnetic susceptibility profiles (Figure S1) carried out at $1 \mathrm{~cm}$ intervals on board, show no evidence of turbidites or hiatuses in sediment deposition, thus indicating promising records for a cross-basinal study of deglacial history of the ice sheets surrounding Baffin Bay. Sediment cores were stored at $<4^{\circ} \mathrm{C}$ and split lengthways into archive and working halves.

\subsection{Chronology}

Age models were constructed for both cores using Accelerator Mass Spectrometry (AMS) ${ }^{14} \mathrm{C}$ dating of biogenic carbonate. To this end, foraminifera were picked from the $>150 \mu \mathrm{m}$ fraction of processed sediment samples in both cores. Either planktonic (Neogloboquadrina pachyderma sinistral) or mixed benthic foraminifera samples were dated. The selection depended on availability of sufficient material at the intervals of interest and where possible, replicate dates based on planktonic and benthic foraminifera within the same sample were obtained. Also included is one date based on mollusc fragments from core SL 170 . Two methods were used for the radiocarbon dating; traditional ${ }^{14} \mathrm{C}$ measurements with AMS on samples converted to graphite and a new method, where $\mathrm{CO}_{2}$ from ultrasmall amounts ( 0.5 mg) of carbonate (Wacker et al., 2013) were directly analysed with a compact AMS facility equipped with a gas ion source at the Laboratory for Ion Beam Physics, ETH Zurich. 
Some of these samples were also leached before measurement (Bard et al., 2015). There is good agreement between the methods, suggesting the dating procedure is robust.

The chronology for both cores was constructed using BACON (Blaauw and Christen, 2011), a Bayesian accumulation model code using an autoregressive gamma process. The code is opensource and run in the program ' $R$ '. This method of constructing an age-depth model is more flexible than classical age-depth modelling, such as CLAM (Blaauw, 2010), as it allows for variable sedimentation rates between radiocarbon dates. Initially, all AMS ${ }^{14} \mathrm{C}$ radiocarbon dates were considered in the development of the age model. The AMS ${ }^{14} \mathrm{C}$ ages and their associated errors were calibrated within the age-depth modelling process, using the Marine13 radiocarbon age calibration curve (Reimer, 2013). In addition, we applied a local reservoir correction $(\Delta R)$ of $140 \pm 35$ years as estimated from historical but pre-bomb samples (Lloyd et al., 2011), currently used for radiocarbon date calibrations of Disko Bugt sedimentary sequences (Jennings et al., 2014; Lloyd et al., 2011; Ouellet-Bernier et al., 2014; Perner et al., 2013, 2011). Since the local reservoir correction in high latitude regions remains poorly constrained over the deglaciation, we carried out a detailed sensitivity assessment of the chronology of the two cores against the choice of local reservoir correction. These results are thoroughly addressed and the effects of changing local reservoir correction are evaluated in the discussion section 4.2 .

\begin{tabular}{|c|c|c|c|c|c|c|c|c|c|}
\hline $\begin{array}{l}\text { Lab } \\
\text { code }\end{array}$ & $\begin{array}{l}\text { Depth } \\
\text { (cm) }\end{array}$ & Material & $\begin{array}{l}\text { Weight } \\
\text { (mg) }\end{array}$ & $\begin{array}{l}14 C \\
\text { age } \\
\text { (yrs) }\end{array}$ & $\begin{array}{l}14 C \\
(+/- \\
\text { yrs) }\end{array}$ & $\begin{array}{l}14 \mathrm{C} \text { age } \\
\text { benthic - } \\
\text { planktonic }\end{array}$ & $\begin{array}{l}\text { Min age } \\
\text { (yrs BP) }\end{array}$ & $\begin{array}{l}\text { Max age } \\
\text { (yrs BP) }\end{array}$ & $\begin{array}{l}\text { Mean } \\
\text { age (yrs } \\
\text { BP) }\end{array}$ \\
\hline $\begin{array}{l}\text { ETH- } \\
55690\end{array}$ & $97-100$ & $\begin{array}{l}\text { planktonic } \\
(\text { N.pachyderma) and } \\
\text { mixed benthic }\end{array}$ & 0.32 & 9793 & 120 & & 10262 & 10961 & 10592 \\
\hline $\begin{array}{l}\text { Beta- } \\
344508\end{array}$ & $\begin{array}{l}122- \\
125\end{array}$ & $\begin{array}{l}\text { planktonic } \\
\text { (N.pachyderma) and } \\
\text { mixed benthic }\end{array}$ & 4.16 & 10390 & 40 & & 11089 & 11585 & 11262 \\
\hline $\begin{array}{l}\text { ETH- } \\
55691\end{array}$ & $\begin{array}{l}142- \\
145\end{array}$ & mixed benthic & 0.56 & 10997 & 110 & & 11512 & 12346 & 12018 \\
\hline $\begin{array}{l}\text { ETH- } \\
58356\end{array}$ & $\begin{array}{l}169- \\
170\end{array}$ & mixed benthic & 0.91 & 11010 & 85 & & 12088 & 12586 & 12370 \\
\hline $\begin{array}{l}\text { Beta - } \\
344505\end{array}$ & $\begin{array}{l}196- \\
199\end{array}$ & $\begin{array}{l}\text { planktonic }(N . \\
\text { pachyderma) }\end{array}$ & 8.54 & 11410 & 50 & & & & \\
\hline $\begin{array}{l}\text { Beta - } \\
344506\end{array}$ & $\begin{array}{l}196- \\
199\end{array}$ & mixed benthic & 12.72 & 11150 & 50 & -260 & & & \\
\hline $\begin{array}{l}\text { KIA } \\
40767\end{array}$ & $\begin{array}{l}215- \\
219\end{array}$ & $\begin{array}{l}\text { planktonic }(N . \\
\text { pachyderma) }\end{array}$ & 1.1 & 12000 & 80 & & 13035 & 13514 & 13288 \\
\hline
\end{tabular}




\begin{tabular}{|c|c|c|c|c|c|c|c|c|}
\hline $\begin{array}{l}\text { Beta - } \\
344507\end{array}$ & $\begin{array}{l}233- \\
236\end{array}$ & $\begin{array}{l}\text { planktonic (N. } \\
\text { pachyderma) }\end{array}$ & 3.42 & 12580 & 60 & 13569 & 14134 & 13.879 \\
\hline $\begin{array}{l}\text { ETH- } \\
58357\end{array}$ & $\begin{array}{l}278- \\
279\end{array}$ & $\begin{array}{l}\text { planktonic (N. } \\
\text { pachyderma) }\end{array}$ & 0.91 & 14510 & 120 & 15852 & 17401 & 16807 \\
\hline $\begin{array}{l}\text { ETH- } \\
58358\end{array}$ & $\begin{array}{l}294- \\
295\end{array}$ & $\begin{array}{l}\text { planktonic (N. } \\
\text { pachyderma) }\end{array}$ & 0.98 & 15060 & 110 & 17122 & 17984 & 17587 \\
\hline $\begin{array}{l}{ }^{*} \mathrm{ETH}- \\
58360.1\end{array}$ & $\begin{array}{l}384- \\
385\end{array}$ & $\begin{array}{l}\text { planktonic }(N . \\
\text { pachyderma) }\end{array}$ & 0.57 & 22380 & 289 & & & \\
\hline $\begin{array}{l}{ }^{*} \text { ETH- } \\
58360.3\end{array}$ & $\begin{array}{l}384- \\
385\end{array}$ & $\begin{array}{l}\text { planktonic }(N . \\
\text { pachyderma) } \\
\text { replicate }\end{array}$ & 0.73 & 22640 & 190 & & & J \\
\hline
\end{tabular}

141 Table 1. Radiocarbon dates and modelled ages for core SL 174 . All ${ }^{14} \mathrm{C}$ radiocarbon dates with the ETH lab code 142 were measured as gas samples for this study at the Laboratory for Ion Beam Physics, ETHZ; other codes are for $143{ }^{14} \mathrm{C}$ dates measured using the traditional $\mathrm{AMS}{ }^{14} \mathrm{C}$ method. All ${ }^{14} \mathrm{C}$ ages were calibrated using the Marine13 144 dataset (Reimer, 2013) and a $\triangle R$ of $140 \pm 35$ years was applied in the age modelling software BACON.

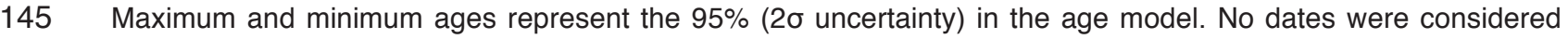
outliers by the BACON age model. *The ages obtained from sample interval $384-385 \mathrm{~cm}$ were not included in the deglacial age model (see text for details).

\begin{tabular}{|c|c|c|c|c|c|c|c|c|c|}
\hline Lab code & $\begin{array}{l}\text { Depth } \\
\text { (cm) }\end{array}$ & Material & $\begin{array}{l}\text { Weight } \\
\text { (mg) }\end{array}$ & $\begin{array}{l}{ }^{14} \mathrm{C} \\
\text { age } \\
\text { (yrs) }\end{array}$ & $\begin{array}{l}{ }^{14} \mathrm{C} \\
(+/- \\
\text { yrs) }\end{array}$ & $\begin{array}{l}{ }^{14} \mathrm{C} \text { age } \\
\text { benthic - } \\
\text { plankton }\end{array}$ & $\begin{array}{l}\text { Min age } \\
\text { (yrs BP) }\end{array}$ & $\begin{array}{l}\text { Max age } \\
\text { (yrs BP) }\end{array}$ & $\begin{array}{l}\text { Mean age } \\
\text { (yrs BP) }\end{array}$ \\
\hline ETH-55678 & $24-27$ & mixed benthic & 0.47 & 9668 & 112 & & 9930 & 10432 & 10226 \\
\hline ETH-55679 & $35-37$ & mixed benthic & 0.81 & 9460 & 80 & & 10095 & 10500 & 10310 \\
\hline ETH-55680 & $55-57$ & mixed benthic & 1.03 & 9833 & 83 & & 10376 & 10747 & 10572 \\
\hline ETH-55681 & $74-76$ & $\begin{array}{l}\text { planktonic }(N . \\
\text { pachyderma) }\end{array}$ & 0.79 & 9901 & 82 & & & & \\
\hline $\begin{array}{l}\text { ETH- } \\
55682.1\end{array}$ & $74-76$ & mixed benthic & 0.87 & 10028 & 87 & 127 & 10652 & 10966 & 10797 \\
\hline $\begin{array}{l}\text { ETH- } \\
55682.2\end{array}$ & $74-76$ & $\begin{array}{l}\text { mixed benthic } \\
\text { (replicate) }\end{array}$ & 0.86 & 10090 & 97 & 189 & & & \\
\hline $\begin{array}{l}\text { ETH- } \\
55683.1\end{array}$ & $98-100$ & mixed benthic & 0.81 & 10243 & 80 & & & & \\
\hline $\begin{array}{l}\text { ETH- } \\
55683.2\end{array}$ & $98-100$ & $\begin{array}{l}\text { mixed benthic } \\
\text { (replicate) }\end{array}$ & 0.90 & 10232 & 137 & & & & \\
\hline ETH-55684 & $116-118$ & $\begin{array}{l}\text { planktonic }(N . \\
\text { pachyderma) }\end{array}$ & 0.44 & 11042 & 107 & & & & \\
\hline ETH-55685 & $116-118$ & mixed benthic & 0.93 & 10274 & 86 & & 11012 & 11471 & 11213 \\
\hline
\end{tabular}




\begin{tabular}{|c|c|c|c|c|c|c|c|c|c|}
\hline $\begin{array}{l}\text { Beta - } \\
344504\end{array}$ & $136-139$ & mollusc fragments & 12.22 & 10080 & 50 & & & & \\
\hline ETH-55686 & $136-139$ & mixed benthic & 0.71 & 12990 & 117 & & & & \\
\hline ETH-58351 & $159-160$ & mollusc fragments & 0.85 & 10755 & 85 & & \multirow{2}{*}{11380} & \multirow{2}{*}{11974} & \multirow{2}{*}{11694} \\
\hline ETH-58352 & $159-160$ & mixed benthic & 0.96 & 10905 & 85 & & & & \\
\hline ETH-58353 & $180-181$ & mixed benthic & 1.08 & 10671 & 85 & & 11516 & 12105 & 11845 \\
\hline ETH-55687 & $266-269$ & mixed benthic & 0.92 & 11267 & 100 & & 12251 & 12656 & 12498 \\
\hline ETH-58354 & $288-290$ & mixed benthic & 0.97 & 11150 & 75 & & 12414 & 12739 & 12601 \\
\hline ETH-55688 & $399-402$ & $\begin{array}{l}\text { planktonic (N. } \\
\text { pachyderma) }\end{array}$ & 0.69 & 11597 & 104 & & \multirow{2}{*}{13040} & \multirow{2}{*}{13369} & \multirow{2}{*}{13213} \\
\hline ETH-55689 & $399-402$ & mixed benthic & 0.87 & 11944 & 92 & 347 & & & \\
\hline KIA 40766 & $484-488$ & $\begin{array}{l}\text { planktonic }(N . \\
\text { pachyderma) }\end{array}$ & 1.20 & 12730 & 60 & & 13879 & 14573 & 14138 \\
\hline ETH-58355 & $636-637$ & $\begin{array}{l}\text { planktonic (N. } \\
\text { pachyderma) }\end{array}$ & 0.85 & 14640 & 130 & & 16435 & 17462 & 16992 \\
\hline
\end{tabular}

Table 2. Radiocarbon dates and modelled ages for core SL 170 . All ${ }^{14} \mathrm{C}$ radiocarbon dates with the ETH lab code were measured for this study as gas samples at the Laboratory for lon Beam Physics, ETHZ; other codes are for ${ }^{14} \mathrm{C}$ dates measured using the traditional AMS ${ }^{14} \mathrm{C}$ method. All ${ }^{14} \mathrm{C}$ were calibrated using the Marine13 dataset (Reimer, 2013) and a $\Delta R$ of $140 \pm 35$ years was applied in the age modelling software BACON. Maximum and

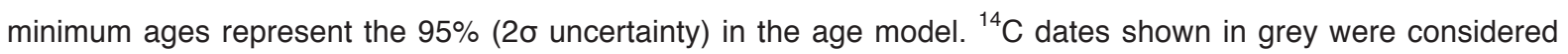
outliers and thus removed from the final age model presented here (see supplementary information for details).

\subsection{Physical sediment properties}

Computerised tomography (CT) and high-resolution colour linescan (LS) imaging were carried out on the archive halves of both cores at the University of Bremen, Germany. Lithofacies were determined from these along with visual analysis, with particular interest in areas of coarser, potentially ice-rafted sediment (Figures 2 and 3). $L^{*}$, a measure of lightness and component of the $C I E / L^{*} a^{*} b^{*}$ colour space, was measured during linescan image acquisition. $L^{*}$ is unit-less value, but represents lightness (in this case of sediment) on a scale from darkest black $\left(L^{*}=0\right)$ to brightest white $\left(L^{*}=100\right)$. $L^{*}$ values are often used as a proxy for relative carbonate content in marine sediment cores; high $L^{*}$ values indicating higher carbonate content (e.g. Balsam et al., 1999). To determine grain size distribution 
throughout the core and also to obtain samples for radiocarbon dating, the working half of both cores was continuously sampled in slices of $1 \mathrm{~cm}$ thick slices. A portion of the slice corresponding approximately to $10 \mathrm{~g}$ dry weight was freeze dried, weighed, washed over $0.063 \mathrm{~mm}$ screen until all fine fraction was removed, the sieve residue was collected, dried and weighed again. The proportion of sediment in this $>63 \mu \mathrm{m}$ fraction was calculated as the ratio between the dry weight of the residue and dry weight of the bulk sample.

\subsection{X-ray fluorescence (XRF) and quantitative $X$-ray diffraction ( $q X R D)$ analysis}

XRF scanning was used to determine elemental properties in the cores. Data were collected every $1 \mathrm{~cm}$ along the archive half surface of both cores with the XRF Core Scanner II $^{\mathrm{TM}}\left(\right.$ AVAATECH $^{\mathrm{TM}}$ serial No. 2) at MARUM, University of Bremen. Sediment intervals containing large amounts of calcium $(\mathrm{Ca})$ were noted, as in previous studies, as an indication of detrital input from source areas surrounding northern Baffin Bay (Aksu and Piper, 1987; Andrews et al., 2014, 1985; Simon et al., 2014). These potential detrital carbonate layers were sub-sampled for qXRD analysis to establish their mineralogy. qXRD was measured on a Bruker D8 Advance ${ }^{\mathrm{TM}}$ diffractometer at the University of Bremen. Of particular interest was the proportion of dolomite and calcite within detrital carbonate rich layers. For full details of XRF and qXRD methods see supplementary information.

\section{Results}

\subsection{Deglacial chronology}

The chronology of the two sediment cores is based on a total of 28 radiocarbon dates (Table 1 and 2 ). The distribution of the calibrated ages reveals that the uppermost portions of both cores, which contained fine-grained sediment and were barren of biogenic carbonate, corresponds to the later part of the Holocene with oldest ages being > $10 \mathrm{kyr}$ BP (Table 1 and 2). The age models of both cores reveal continuous deposition during the last deglacial and early Holocene period ( 17-10 kyr BP), albeit at different resolutions. The interval of highest sedimentation rates and thus of clastic delivery appears synchronous across the two cores $(\sim 12.6 \mathrm{kyr} B \mathrm{P})$.

In core SL 174, the barren Holocene section corresponds to the top $98 \mathrm{~cm}$. Further downcore, the progression of ages indicates undisturbed sedimentation (Figure 2). As a result, the Bayesian age model could be constructed using all ages, including a replicate age measurement on both planktonic 
and benthic foraminifera in one sample interval. A large amount of planktonic foraminifera in the sample interval 384-385 cm allowed for a technical replicate; the extracted foraminifera were split and resulting aliquots were dated separately. The replicate planktonic-benthic age differed by about the same amount as the technical replicate in the oldest dated sample at $384-385 \mathrm{~cm}\left(260{ }^{14} \mathrm{C}\right.$ years) (Table 1). A (calibrated) date of $\sim 17.6 \mathrm{kyr}$ BP at $294-295 \mathrm{~cm}$ is the first date bracketing the deglacial period. An older (calibrated) ${ }^{14} \mathrm{C}$ age of $\sim 26.2 \mathrm{kyr}$ BP obtained from $384-385 \mathrm{~cm}$ indicates that the lower part of the sediment sequence in the core is older than the LGM. The overlying 10 radiocarbon dates included in the age model indicate that the corresponding $197 \mathrm{~cm}$-long interval covers the period $17.6-10.6 \mathrm{kyr}$ BP (Figure 2). The initial part of the deglacial record of SL 174 is characterised by low sedimentation rates of $14-23 \mathrm{~cm} \mathrm{kyr}^{-1}$ up to $234 \mathrm{~cm}$ downcore ( 13.9 kyr BP), above it increasing about twofold to 28-32 $\mathrm{cm} \mathrm{kyr}^{-1}$. Highest sedimentation rates of 85-95 $\mathrm{cm} \mathrm{kyr}^{-1} \mathrm{are}^{2}$ observed between 197 and $143 \mathrm{~cm}(\sim 12.7-12.0 \mathrm{kyr}$ BP).

A total of $21{ }^{14} \mathrm{C}$ ages, including 3 planktonic-benthic replicate ages, 2 benthic (technical) replicates and 2 benthic-mollusc fragment replicate ages were obtained for core SL 170 (Table 2). There were insufficient foraminifera in the top $24 \mathrm{~cm}$ and bottom $46 \mathrm{~cm}$ of the core for radiocarbon dating. Three radiocarbon ages fell outside the $95 \%$ uncertainty range of the age-depth model (see Figure S2 and supplementary information for details). These ages were removed from the final age model run, including one replicate planktonic age $(116-118 \mathrm{~cm})$ and two replicate benthic-mollusc fragment ages $(136-139 \mathrm{~cm})$. The remaining replicates showed excellent reproducibility, with plankton-benthos age differences of the same size as differences between benthic replicates. Based on the retained 18 ages, the corresponding $613 \mathrm{~cm}$ sedimentary sequence could be dated to the period $\sim 17.0-10.2 \mathrm{kyr}$ BP (Figure 3). The calculated sedimentation rate was low ( $\left.56 \mathrm{~cm} \mathrm{kyr}^{-1}\right)$ during the deposition of the 636-486 cm interval ( 17.0-14.1 kyr BP). A twofold increase in sedimentation rate (up to $\sim 96 \mathrm{~cm} \mathrm{kyr}^{-}$

${ }^{1}$ ) occurred at $\sim 14.1 \mathrm{kyr} \mathrm{BP}$, and from then on the sedimentation rate remained high, varying between 87 and $257 \mathrm{~cm} \mathrm{kyr}^{-1}$ (Figure 3).

\subsection{Physical sediment properties}

In core SL 174 the interval $295-240 \mathrm{~cm}(\sim 17.6-14.2 \mathrm{kyr}$ BP) is characterised by laminated muds (Figure 2). Within this interval, the $>63 \mu \mathrm{m}$ fraction remains below $20 \%$ and $L^{*}$ values fluctuate 
around 45. The following section is coarsening upward towards a thick layer of massive pebbly mud between 240-195 cm ( 14.2-12.6 kyr BP). Gravel-sized clasts embedded in the finer matrix, likely representing dropstones, are abundant within this interval. Between 195 and $163 \mathrm{~cm}(\sim 12.6-2.2 \mathrm{kyr}$ BP), a layer of darker sediment ( $L^{*}$ value $\sim 40$ ) composed of a finer laminated mud, with lower $>63$ $\mu \mathrm{m}$ fraction content $(\leq 10 \%)$. A layer of massive pebbly mud, with dropstones, $30 \%>63 \mu \mathrm{m}$ fraction and $L^{*}$ values of $50-60$, are found between $163-111 \mathrm{~cm}(\sim 12.2-10.9 \mathrm{kyr} B P)$. The rest of the core is composed of laminated mud and a much reduced content of the $>63 \mu \mathrm{m}$ fraction. Occasional dropstones are found until $75 \mathrm{~cm}$. A brown mud layer of less than $5 \mathrm{~cm}$ caps the top of the core. 3) with a very low content of the $>63 \mu \mathrm{m}$ fraction. Above $510 \mathrm{~cm}$, a thin layer of pebbly mud with dropstones is followed by a sandy mud layer with a $>63 \mu \mathrm{m}$ fraction content of up to $50 \%$ (505-470 $\mathrm{cm} ;$ 14.5-13.9 kyr BP). Up to $393 \mathrm{~cm}(\sim 13.2 \mathrm{kyr} \mathrm{BP})$, the core then consists of stratified fine muds. Laminated sandy and pebbly muds characterise the sediment from this point on, with abundant dropstones and recognisable bioturbation between 360 and $320 \mathrm{~cm}(\sim 12.9$ to $2.7 \mathrm{kyr} \mathrm{BP})$. Another pebbly layer corresponds to the period $\sim 11.5$ to $11.1 \mathrm{kyr} \mathrm{BP}(145-110 \mathrm{~cm})$. The top $60 \mathrm{~cm}$ of the core is characterised by a sandy mud layer (>63 $\mu \mathrm{m} 10-25 \%)$ with occasional dropstones. While $L^{*}$ values fluctuate here more frequently than in SL 174, coarser layers between 320 and $70 \mathrm{~cm}$ are composed of consistently lighter sediment $\left(\mathrm{L}^{*} \sim 47-49\right)$. The top of the core is capped with $\mathrm{a} \sim 4 \mathrm{~cm}$ thick brown mud layer. 


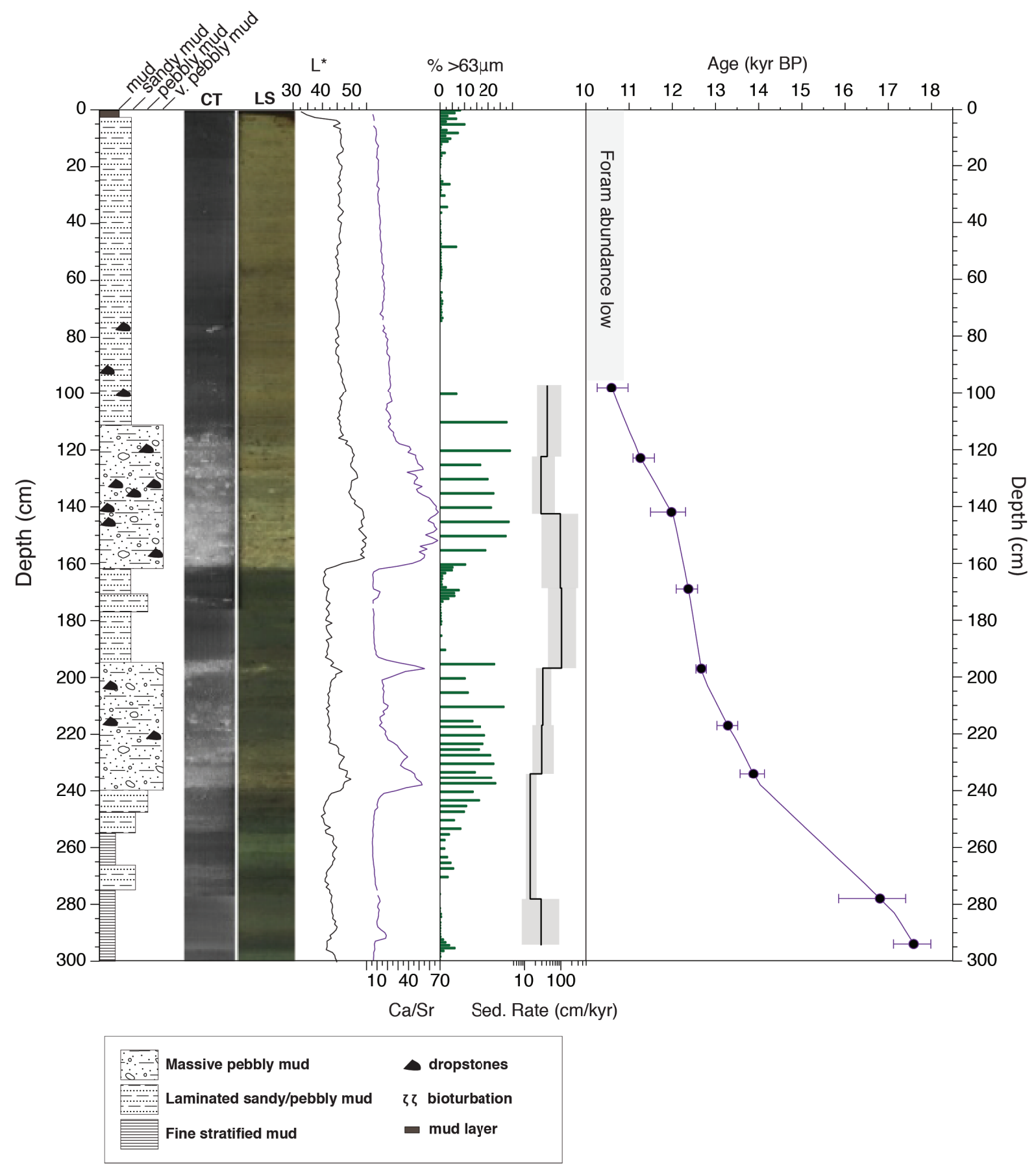

238 Figure 2. Chronology and lithostratigraphy for core SL 174. The age-depth relationship is based on $10{ }^{14} \mathrm{C}$ dates (filled circles). Error bars indicate minimum and maximum ages (95\% uncertainty, $2 \sigma)$ for dated intervals from the age model. Sedimentation rate (shown on log scale) was calculated between each dated interval, the black line

241 indicating the mean sedimentation rate and grey area indicating the error (95\% uncertainty). Computerised tomography (CT) and colour linescan images (LS) are shown as well as sediment lightness $\left(\mathrm{L}^{*}\right)$ measurements. The percentage of sediment $>63 \mu \mathrm{m}$ is shown in green. $\mathrm{Ca} / \mathrm{Sr}$ ratio downcore is shown in purple. The lithofacies are defined from CT, LS images and visual inspection of the core. 


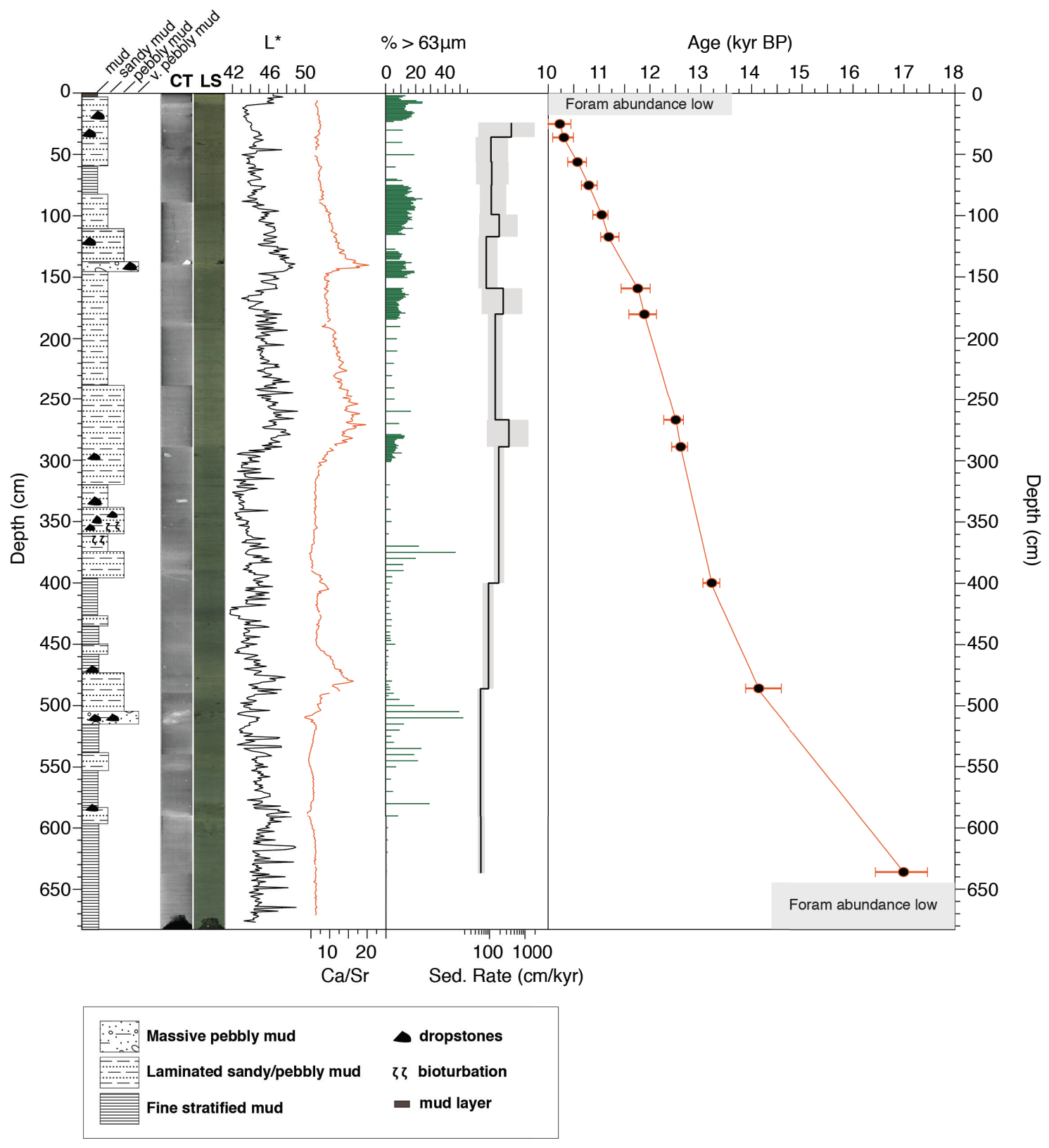

245 Figure 3. Chronology and lithostratigraphy for core SL 170. The age-depth relationship is based on $18{ }^{14} \mathrm{C}$ dates

246 (filled circles). Error bars indicate minimum and maximum ages (95\% uncertainty, $2 \sigma)$ for dated intervals from the 247 age model. Sedimentation rate (shown on log scale) was calculated between each dated interval, the black line indicating the mean sedimentation rate and grey area indicating the error (95\% uncertainty). Computerised tomography $(\mathrm{CT})$ and colour linescan images (LS) are shown as well as sediment lightness $\left(\mathrm{L}^{*}\right)$ measurements.

250 The percentage of sediment $>63 \mu \mathrm{m}$ is shown in green. $\mathrm{Ca} / \mathrm{Sr}$ ratio downcore is shown in orange. The lithofacies are defined from CT, LS images and visual inspection of the core. 
X-ray fluorescence (XRF) scans were used to characterise elemental properties of the sediment and thus identify detrital carbonate layers that were found in this time interval in Baffin Bay sediments during previous studies. We use the ratio of calcium (Ca) to strontium $(\mathrm{Sr})$ counts to define these layers, as used in studies of North Atlantic and Labrador Sea sedimentary sequences, to identify detrital carbonate layers (Channell et al., 2012; Hodell et al., 2008; Pearce et al., 2013; Winsor et al., 2012). In core SL 174, the first increase in $\mathrm{Ca} / \mathrm{Sr}(>30)$ occurs between 240 and $217 \mathrm{~cm}$. A subsequent peak is seen between 200 and $185 \mathrm{~cm}$, and the thickest one between 165 and $115 \mathrm{~cm}$ (Figure 2). Outside these intervals, Ca/Sr values remain between 5 and 30. In core SL 170, three intervals with high $\mathrm{Ca} / \mathrm{Sr}$ ratios $(>15)$ are observed at depths of $510-460,285-190$ and $145-110 \mathrm{~cm}$ (Figure 3). Outside these intervals $\mathrm{Ca} / \mathrm{Sr}$ ratios remain between 5 and 13.

qXRD measurements were carried out on a subset of samples where high $\mathrm{Ca} / \mathrm{Sr}$ values were observed. Of particular interest was the proportion of dolomite and calcite within layers with high $\mathrm{Ca} / \mathrm{Sr}$ values, which were expected to contain detrital carbonate. The results of qXRD analyses indicate that in these carbonate-rich layers from SL 174, total carbonate percentages are between 23 and $55 \%$ with a high proportion of dolomite $(17-40 \%)$ relative to calcite $(7-17 \%)$. The proportion of total carbonate in detrital carbonate layers is lower in SL 170 (4-16\%). However as found in SL 174, there is a consistently higher proportion of dolomite $(4-12 \%)$ as compared to calcite $(1-4 \%)$ in all samples analysed. All data presented here will be made available online at the PANGEA portal.

\section{Discussion}

\subsection{Identification and timing of Baffin Bay detrital carbonate (BBDC) events}

In both cores, the base of the oldest detrital carbonate layer is associated with an almost twofold increase in sedimentation rates. In core SL 174 , the detrital carbonate delivery event is characterised by a very pebbly mud layer with abundant dropstones, possibly indicating iceberg rafting (Figure 2). In SL 170 this layer is associated with the deposition of a less coarse, sandy layer, with occasional dropstones (Figure 3). Within the age model uncertainty, this layer (and thus the event that led to its deposition) appears synchronous on both sides of Baffin Bay, beginning $\sim 14.2 \mathrm{kyr}$ BP and ending 13.7 kyr BP (Figure 4). This event corresponds to the first observed detrital carbonate delivery in 

previous Baffin Bay records (Andrews et al., 2014, 1998, Simon et al., 2014, 2012).

282

A subsequent increase in detrital carbonate input is inferred to start at $\sim 12.7 \mathrm{kyr}$ BP in SL 174 and 12.6 kyr BP in SL 170, i.e. at about the same time within the age model uncertainty. This second detrital carbonate layer is associated with an almost four-fold increase in sedimentation rates in both cores, peaking at $\sim 12.6 \mathrm{kyr}$ BP (Figures 2 and 3) and by lithology and physical properties similar to those of the older BBDC 1 in each core. However, peak accumulation rates at $\sim 12.6 \mathrm{kyr}$ BP are associated with different geochemical signatures on both sides of Baffin Bay. On the Greenland side, the $\mathrm{Ca} / \mathrm{Sr}$ values are at their maximum, whereas on the Baffin Island side, there is a distinct minimum in $\mathrm{Ca} / \mathrm{Sr}$ (Figure 4). The manifestation of this event in SL 174 is almost identical to that observed in the deeper and more northern core PC 16 (Figure 1; Simon et al., 2014, 2012). In both western Baffin Bay cores, this event is characterised by a decrease in the proportion of $>63 \mu \mathrm{m}$ fraction (Figure 2) and an increase in Ti/Sr ratios (Figure S3), a proxy for increased terrigenous (vs. biogenic) input. The common internal structure of this event in both PC 16 and SL 174 could therefore reflect a regional change in the source and pattern of sediment delivery to the basin. Indeed, this finer, Ti-rich sediment is thought to indicate a lateral mode of sediment delivery from ice stream advance/retreat in Baffin Bay (Aksu and Piper, 1987; Hiscott et al., 1989). More recent provenance studies identify a predominantly western Greenland (Uummannaq) source of these fine grained layers (Simon et al., 2014). The end of this event in both cores studied here is characterised by a secondary peak in $\mathrm{Ca} / \mathrm{Sr}$ at $\sim 11.4 \mathrm{kyr}$ BP followed by a gradual decline in $\mathrm{Ca} / \mathrm{Sr}$ until $\sim 11.0 \mathrm{kyr} \mathrm{BP}$. The timing of this event and its structure on the Baffin Island side suggests it is the previously identified BBDC 0 event (Andrews et al., 1995; Jennings et al., 2014; Simon et al., 2014, 2012).

Our identification of these detrital carbonate layers as BBDC layers is further supported by qXRD results (Figure 5). The bulk sediment composition in both BBDC events shows calcite/dolomite ratios consistently lower than $\sim 0.25: 1$ in cores SL174 and SL 170. When compared with core PC 16, the total carbonate and dolomite therein decreases with increasing distance from the northern Baffin Bay source area, to which core PC 16 is most proximal and core SL 170 most distal along the path of the counter-clockwise circulation (Figure 1). This suggests that ice-rafting of dolomite rich carbonates 
from the major northern ice streams, such as Nares Strait/Smith Sound and Lancaster Sound, followed the southward path of the present-day Baffin Island current and re-circulated east toward the centre of Baffin Bay north off Davis Strait (Figure 1), as also suggested by Andrews et al. (2011). The composition of the BBDC 1 layer is distinctly different from Heinrich Event 1 layers from the Hudson Strait (Andrews et al., 2012, 1995) and from this we can assume that icebergs discharged from the Hudson Strait did not recirculate north into Baffin Bay (Figure 5) BBDC 0 has a higher proportion of carbonate (and dolomite) perhaps indicating larger amounts of detrital carbonate among the ice rafted debris than during the deposition of BBDC 1. In fact, composition of the presumed $\mathrm{HO}$ event in the Labrador Sea has a distinct signature more closely following that of BBDC events in the Baffin Bay (Figure 5).

318 The synchronous nature of the BBDC 1 and 0 events that span Baffin Bay provides evidence for two periods of major North American-Arctic ice-sheet instability events Baffin Bay during the last deglaciation. This model of sediment delivery (Andrews et al., 1998; Hiscott et al., 1989) explains the sedimentation pattern along the Baffin Island margin (PC 16 and SL 174), but the higher sedimentation rate in SL 170 during both BBDC events requires an additional, local source of sediment during these events. The proximity of SL 170 to the paleo-ice streams of Disko Bugt suggests material delivered by the dynamic Jakobshavn Isbrae as the most likely local source of clastic sediment. Indeed, these ice streams retreated via iceberg calving during the interval of BBDC 0 (Jennings et al., 2014) and sediment originating from nearby west Greenland could have potentially caused dilution of the carbonate-rich signal in SL 170. 


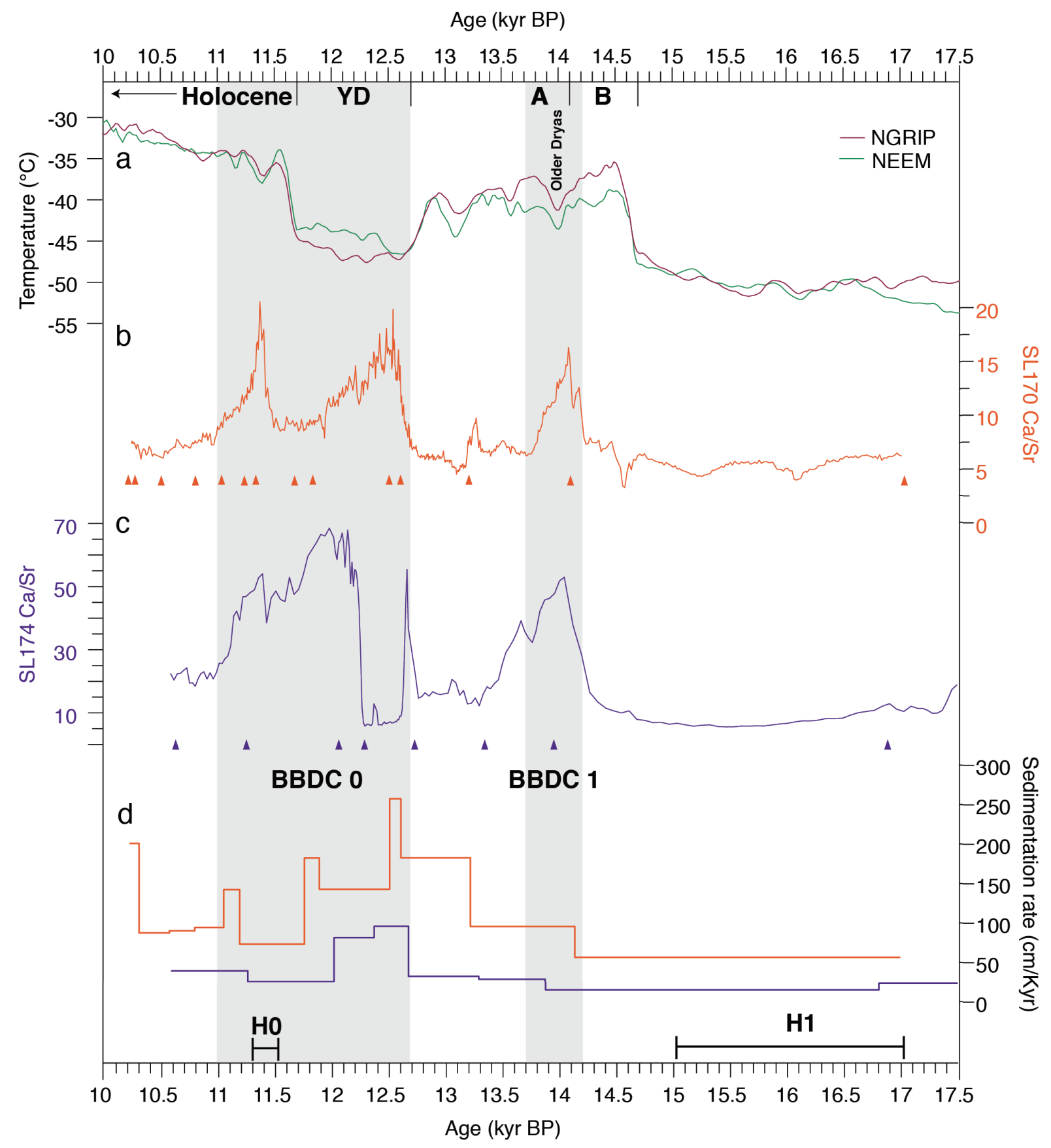

Figure 4. Timing of BBDC events in central Baffin Bay during the last deglaciation. Elevated $\mathrm{Ca} / \mathrm{Sr}$ ratios for $\mathrm{SL}$ 170 (b) and SL 174 (c) depict the two major BBDC events during the deglaciation, highlighted by grey shading. Radiocarbon dates for each record are shown by triangles of corresponding colour. Average sedimentation rates are also shown for both cores in the corresponding colour (d). BBDC 1 post-dates the onset of Bølling warming (B) and continues into the Allerød (A) indicated by new analysis of Greenland ice core records (a) (Buizert et al., 2014) and the Heinrich 1 Event (H1) in the Atlantic (Carlson and Clark, 2012) (d). BBDC 0 occurs at the onset of the Younger Dryas (YD) stadial and ends apparently slightly after the YD-end, possibly overlapping the newest timing of North Atlantic Heinrich Event 0 in the Labrador Sea (d) (Jennings et al., 2015; Pearce et al., 2015). 


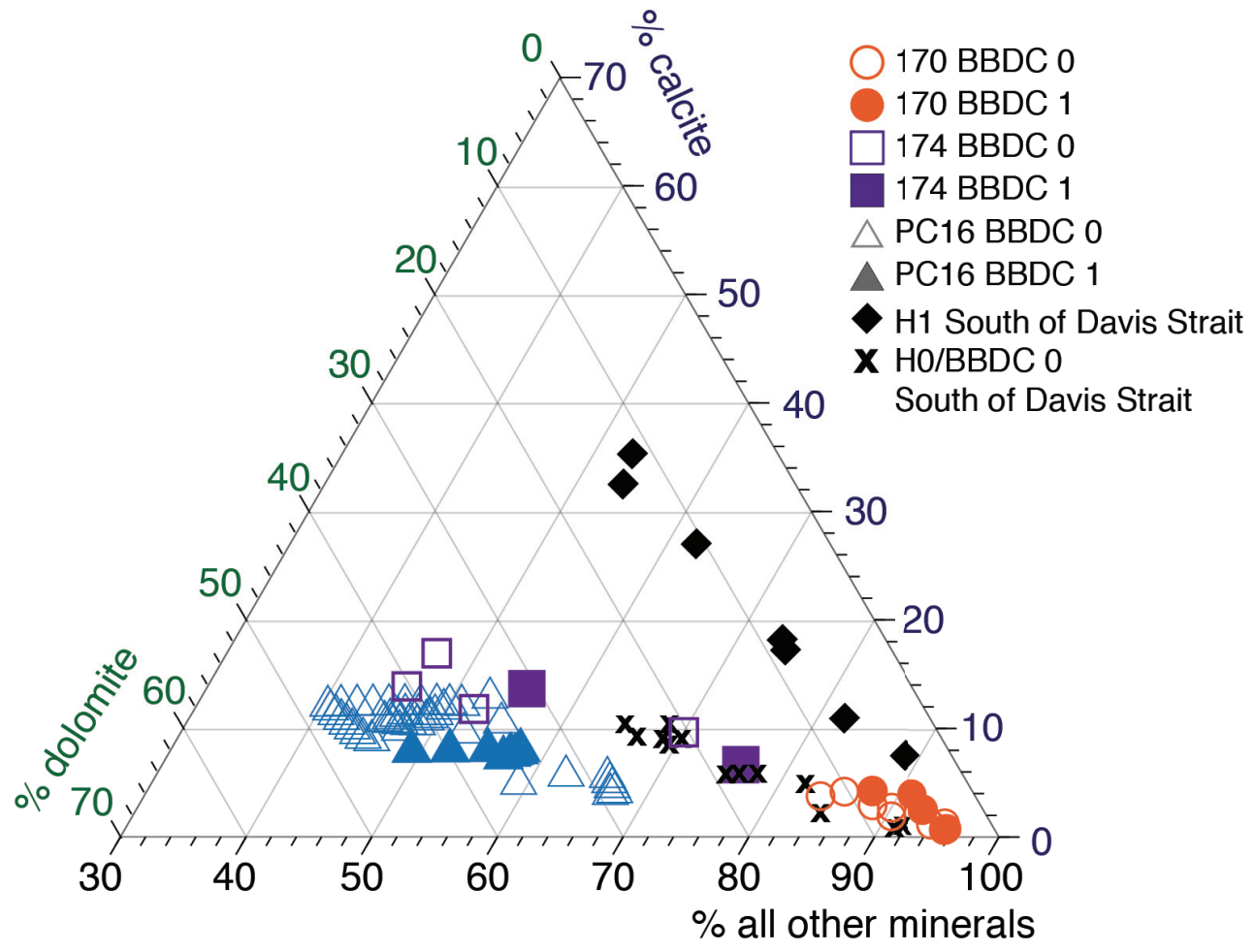

Figure 5. Detrital carbonate composition during BBDC events in central Baffin Bay. Core PC 16 (Simon et al., 2014) has the highest concentration of carbonate and dolomite whilst the most distal core (SL170, this study) has the lowest. Composition of detrital carbonate layers found south of the Davis Strait (HU97048-007PC and HU87033-009) during Heinrich Event 1 are shown for comparison. Layers depositing during the presumed HO/BBDC 0 event have a higher dolomite component within detrital carbonate layers (Andrews et al., 2014, 2012). Allocation of these sediments to Heinrich layer timing is based on the original age models for these cores. 4.2 Age uncertainty due to variable local ${ }^{14} \mathrm{C}$ reservoir effect in Baffin Bay The construction of a radiocarbon chronology and dating of the observed abrupt ice-sheet instabilities are associated with uncertainties, which deserve consideration prior to full discussion of their relation to regional as well as global climatic changes. Of particular importance is the effect of a local ${ }^{14} \mathrm{C}$ reservoir age $(\Delta R)$ in Baffin Bay; the magnitude and variability of which is not well constrained (e.g. Pearce et al., 2015). Previous radiocarbon chronologies in Baffin Bay and surrounding regions have employed $\Delta R$ values ranging from 0 years (e.g. Levac et al., 2001; Knudsen et al., 2008; Gibb et al., 2015) to 400 years in the northern Baffin Bay (e.g. Ledu et al., 2010). Recent studies in the Disko Bugt area use a $\Delta R$ of $140 \pm 35$ yrs (Jennings et al., 2014; Lloyd et al., 2011; Ouellet-Bernier et al., 2014; Perner et al., 2013, 2011), estimated from historical but pre-bomb samples. Using $\Delta R=140 \pm$ 
$35 \mathrm{yrs}$ at the site of SL 174 is also in line with studies of regional reservoir correction in Arctic Canada, that indicate local reservoir correction of $\Delta R=150 \pm 60 \mathrm{yrs}$ in the south east Baffin Island region (Coulthard et al., 2010). No studies to-date address radiocarbon dating and the effect of $\Delta R$ in the region of the deeper cores used here. Furthermore, we lack dateable material independent of any reservoir effect (e.g., pollen or tephra), in order to test for reservoir effects.

Instead, to assess potential variability in the timing of the observed BBDC events, we generated multiple age models with BACON under same settings but varying the $\Delta R$ and its associated uncertainty $( \pm)$. Due to the higher resolution and higher number of available ${ }^{14} \mathrm{C}$ dates we focused on the core SL 170 and tested the impact of changing $\Delta R$ on the onset and termination of BBDC events (at $\mathrm{cm}$ depth). The results can be seen in Figure 6. While increasing $\Delta R$ from the published standard of $\Delta R=140 \pm 35 \mathrm{yrs}$ (total correction $=\sim 540 \pm 35 \mathrm{yrs}$ ) to $\Delta R=400 \pm 100 \mathrm{yrs}$ (total correction $=\sim 800$ $\pm 100 \mathrm{yrs}$ ) has the expected effect of making these events younger, the onset of the events even after application of these variable corrections remains within the $95 \%$ confidence intervals of the original age model. Importantly, none of the corrections align the timing of these events with Greenland temperature changes or Hudson Strait Heinrich Events (Figure 6).

Three sample intervals at depths $74-76 \mathrm{~cm}$ (SL 170), 399-402 cm (SL 170) and 196-199 cm (SL 174) yielded enough material for planktonic and benthic radiocarbon dating, providing potentially another means of assessing $\Delta R$ (Tables 1 and 2). The (uncalibrated) difference in ${ }^{14} \mathrm{C}$ ages between planktonic and benthic ranges from 127 to $347 \mathrm{yrs}($ mean $=221$, standard deviation $=113$ ) in core SL 170 , whereas the planktonic age SL 174 is 260 years older than the benthic age. This is a feature occasionally observed in deep sea sediments and assigned either to the export of fresh young carbon from the photic zone to the sea floor or to distinct ventilation ages of sub-surface versus bottom waters (Bauer et al., 1995; Lund et al., 2011; Wu and Hillaire-Marcel, 1994). Whilst this does not permit a quantitative assessment of the offset between planktonic and benthic radiocarbon dates, it gives an indication that the difference does not vary by more than a few centuries. This small difference also allows us to accept the two-topmost dates (Holocene) for SL 174, which, due to low abundance of planktonic and benthic foraminifera, required a mixed sample for dating (Table 1). 
379 A $\Delta R=140 \pm 35 \mathrm{yrs}$ (total correction $=540 \pm 35 \mathrm{yrs}$ ) is more than likely sufficient for correcting ages 380 based on planktonic foraminifera. While Baffin Bay is and was subject to extensive and persistent sea-ice cover, planktonic foraminifera would inhabit the top $\sim 150 \mathrm{~m}$ of the water column, with well ventilated water (Figure 1). Although our planktonic and benthic dates agree with each other (Tables 1 and 2), we nonetheless tested the difference between applying $\Delta R=140 \pm 35 \mathrm{yrs}$ to all radiocarbon dates (age model presented here) and keeping the $\Delta R$ the same for radiocarbon ages based on planktonic foraminifera, while increasing it to $\Delta R=400 \pm 50 \mathrm{yrs}$ for radiocarbon ages based on benthic foraminifera (Figure 6; variable $\Delta R$ ). This also has the effect of making the onset and termination of the BBDC 0 event younger, but the new dates remain within the uncertainty $(95 \%$ confidence interval) of the original age model. Differences are minimal in the deeper sections of both cores (BBDC 1), where most pre-Younger Dryas ${ }^{14} \mathrm{C}$ dates are based on planktonic samples. Small differences between models for core SL 174 (Figure 6), where most dates are based on planktonic material, also supports this finding. The disintegration of the Greenland and Innuitian (Ellesmere) ice sheets and subsequent opening of the Nares Strait was not achieved before $\sim 10 \mathrm{kyr}$ BP (Jennings et al., 2011; Zreda et al., 1999), so the effect on the age model of poorly-ventilated (older) Arctic water entering Baffin Bay can be largely disregarded.

The variability of $\Delta R$ through time is unknown in Baffin Bay. A larger $\Delta R$ correction of $700-800 \mathrm{yrs}$ was found to be appropriate for the North Atlantic during the Younger Dryas stadial, owing to enhanced sea ice cover and reduced advection of surface waters into the area (Bard et al., 1994). The potential that $\Delta R$ could have been larger during the Younger Dryas and the early part of the last deglacial period is something that we cannot quantify in this study. However previous studies in Baffin Bay indicate that extensive sea ice conditions persisted throughout the deglacial until the early Holocene 7.4-7.3 kyr BP (Gibb et al., 2015; Ouellet-Bernier et al., 2014). From this we could make the assumption that if there is an additional sea-ice correction needed, it would remain relatively constant. Nonetheless, the age model, run with various reservoir ages (Figure 6), gives us an indication as to the effect of increasing reservoir ages on the timing of the recorded Baffin Bay Detrital Carbonate events. Unless using a very high negative reservoir correction, it is not possible to align BBDC 1 with Heinrich Event 1 as recorded in the North Atlantic (Figure 4). The possibility that BBDC 
al., (1997) suggested H0 onset at $12.8 \mathrm{kyr}$ BP, more recent work (Hillaire-Marcel and de Vernal, 2008; Jennings et al., 2015; Pearce et al., 2015), points to a much younger age $\sim 11.5 \mathrm{kyr} B P$, at the very end of the Younger Dryas (Figures 4 and 7$)$. The onset of BBDC 1 inferred in this study $(\sim 14.1$ kyr BP) is $\sim 2400$ years younger than the revised onset of HO. This would require applying an extremely high $\Delta R>2000$ years to planktonic radiocarbon dates, which we consider unrealistic. Applying such high reservoir correction would imply that BBDC 0 post-dated the main discharge events from the Disko Bay (Jennings et al., 2014).

In summary, the sensitivity study indicates that the age model using the published local reservoir ( $\Delta R$ $=140 \pm 35 \mathrm{yrs})$ on all radiocarbon dates is unlikely to be affected by variable reservoir age effects to such degree that it would allow alternative phase relationship with Greenland temperatures and Labrador Sea Heinrich Events (Figure 4).

Besides local reservoir correction, the possibility of detrital carbonate contamination of the foraminifera tests used for radiocarbon dating, particularly within BBDC layers, also requires discussion. We noted previously that detrital carbonate delivered to the study core sites is likely of Paleozoic age; thus even a minute amount of contamination would yield either substantially older or 'blank' ${ }^{14} \mathrm{C}$ ages, i.e. beyond the range of radiocarbon dating. Radiocarbon dates within a detrital carbonate layer representing the $8.2 \mathrm{kyr}$ BP event in Laurentian Fan sedimentary sequences, for example, required additional reservoir correction; Lake Agassiz waters were depleted in ${ }^{14} \mathrm{C}$ due to underlying Palaeozoic carbonates (Hoffman et al., 2012). Only three radiocarbon ages (including one replicate) had to be removed from the final age model of SL 170 (Table 2) as they caused small reversals (Figures S2). No age reversals occurred in SL 174 (Table 1). Comparisons of dates within BBDC layers with those outside them are consistently well within the error of the age-depth relationship and we can conclude from this that there was little contamination effect. Although the potential impact of a contamination by Palaeozoic carbonate would be significantly more important on ${ }^{14} \mathrm{C}$-dating than on stable isotope compositions of foraminifera, it is noteworthy that stable isotopes measurements in the northwest Labrador Sea of 'dirty' vs. 'clean' foraminifera tests, did not yield significant differences; the 'dirty' foraminifera tests, extracted from detrital carbonate-rich layers, 


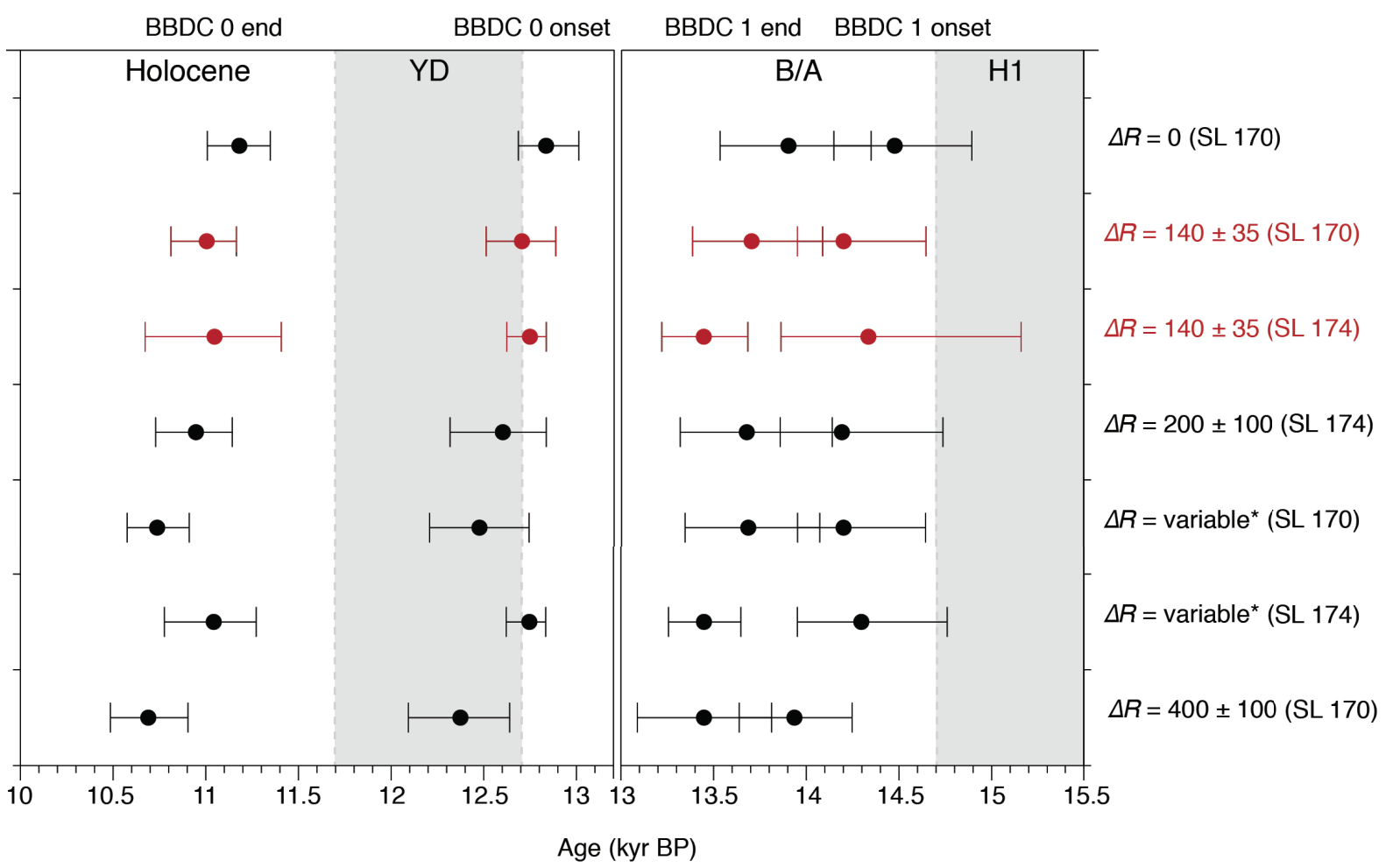

Figure 6. Testing the effect of local reservoir age on the timing of detrital carbonate events in the studied central Baffin Bay cores. Modelled age (kyr BP) for the onset and end of BBDC events 1 and 0 in both cores, using differing local reservoir age $(\Delta R)$ and associated uncertainty $(\Delta R \pm)$ are shown. All other model-run parameters were kept the same. *variable $\Delta R$ run applied a $\Delta R=140 \pm 35 \mathrm{yrs}$ to planktonics and $\Delta R=400 \pm 50 \mathrm{yrs}$ to benthics ${ }^{14} \mathrm{C}$ dates. Shaded intervals refer to climatic events during the Holocene; $\mathrm{YD}=$ Younger Dryas, $\mathrm{B} / \mathrm{A}=$ Bølling/Allerød, $\mathrm{H} 1$ = Heinrich Event 1

\subsection{Asynchronous ice sheet instability during the last deglaciation}

From the Last Glacial Maximum until BBDC 1, there is no evidence for enhanced detrital carbonate delivery to the Baffin Bay (see also Simon et al., 2014), suggesting only minimal discharge from any of the surrounding ice sheets until $14.2 \mathrm{kyr}$ BP. Our results confirm earlier inferences about the unlikeliness of a Heinrich Event 1 equivalent in Baffin Bay (Andrews et al., 2014, 1998, Simon et al., 2014, 2012) (Figures 4 and 7). Outside of BBDC layers, we observe no sedimentary evidence for any major ice sheet instability. Although precise sediment provenance data are not available, it appears that there is an out-of-phase relationship between the North American Arctic and western Greenland 
ice sheets discharging into Baffin Bay and the Laurentide Ice Sheet calving via the Hudson Strait. Our age model test runs (see section 4.2) indicate that this out of phase behaviour is unlikely to be caused by variable local reservoir ages. The conclusion is further supported by the ${ }^{14} \mathrm{C}$ date in SL 174 at $384-$ $385 \mathrm{~cm}$, with an (uncalibrated) age of $\sim 22.3-22.6 \mathrm{kyr}$ BP. Although not included in the age model, it indicates the continuation of low sedimentation rates during the glacial period and thus no enhanced detrital input during Heinrich stadial 1. Furthermore, no Heinrich Event 1 equivalent event was noted in PC 16, north of SL 174 (Simon et al., 2014, 2012).

Contrary to earlier inferences (Simon et al., 2014, 2012), our high-resolution age model indicates that the onset of BBDC 1 postdates the onset of the Bølling interstadial as expressed in northern Greenland atmospheric temperatures (Buizert et al., 2014) by 200 years (Figure 4). This difference is outside the $95 \%$ uncertainty in SL 170 and marginally within uncertainty in SL 174, indicating that the observed phase relationship may reflect a real temporal succession. In this scenario, the onset of the BBDC 1 event could reflect a lagged-nonlinear response (Carlson and Winsor, 2012) of the marine-terminating portions of the North American Arctic and western Greenland ice sheets to the Bølling warming. On the one hand, the onset of BBDC 1 occurred at the very end of meltwater pulse 1A (e.g. Deschamps et al., 2012), at the end of a period of rapid postglacial sea level rise. This would potentially deepen sills such as Davis Strait (e.g. Tarasov et al., 2012) (Figure 1) which in turn could have flooded ice margins. However the role of this mechanism would depend on the source of the meltwater pulse (North American and/or Antarctic ice sheets), which is still under debate (e.g. Liu et al., 2015). Thus we cannot directly implicate this as a mechanism for the onset of BBDC 1 in Baffin Bay. On the other hand, the timing of the BBDC 1 onset follows the spreading of warm water in the deep North Atlantic (Thiagarajan et al., 2014) and invigorated circulation (Liu et al., 2009) at the transition into the Bølling interstadial. This could have resulted in a greater inflow of the warm Irminger component of the West Greenland Current into Baffin Bay (Figure 1). The incursion of warmer subsurface water was observed off St. Lawrence (Obbink et al., 2010) and the incursion of warmer Irminger Water was observed off southern Greenland at 14 kyr BP (Jennings et al., 2006; Knutz et al., 2011; Winsor et al., 2012), and there is potential evidence for this incursion prior to 14 kyr BP in the Uummannaq Trough region (Sheldon et al., 2016). This incursion of warm sub-surface water has been implicated as a mechanism for enhancing basal melting of the Uummannaq Trough ice stream 
480 (Sheldon et al., 2016) situated to the north of SL 170. There is little evidence of extensive ice-rafted debris in the BBDC 1 layer in SL 170, but the increased sedimentation rate at $\sim 14.1 \mathrm{kyr}$ BP could reflect increased delivery of local sediment driven by enhanced basal melting along the West Greenland margin (Figure 3), but this requires further investigation.

In western Baffin Bay, BBDC 1 sediments contain significant amounts of detrital carbonates (and abundant dolomite, Figure 5). The coarser sediment, containing abundant dropstones, is more characteristic of ice-rafted deposition. This layer is similar in timing and properties to a DC layer observed in cores from the Uummannauq Trough region (Sheldon et al., 2016) and in PC 16, north of SL 174 (Simon et al., 2014, 2012). Evidence of detrital carbonate layers are also found in the sediments from the Lancaster Sound Trough mouth ( $\mathrm{Li}$ et al., 2011), although these layers remain undated, the authors assigning these events to the Heinrich Event timescale ( $\mathrm{Li}$ et al., 2011). Similarly, records of detrital deposition in the Fram Strait, originating from the Arctic-Innuitian and Laurentide ice sheets, are roughly in line with the timing of the BBDC 1 (Darby and Zimmerman, 2008) (Figure 7). However, Darby and Zimmerman (2008) also suggest that Fram Strait ice-rafted debris (IRD) events could be (with age model uncertainties) a manifestation of Heinrich Events, a suggestion weakened by the chronology proposed here.

Although we cannot identify specific source areas in this study, it appears that the BBDC 1 event follows the model of sediment dispersal first proposed by Aksu and Piper (1987) and Hiscott et al., (1989). In this scenario, massive calving from destabilised ice sheets and glaciers surrounding northern Baffin Bay (North American-Arctic and north-western Greenland) resulted in the deposition of detrital carbonate layers along the path of the WGC/BIC (Figure 7). Whether the destabilisation of the North American-Arctic and western Greenland ice sheets and associated discharge were driven by the incursion of a warmer and stronger WGC (Figure 1) at the study sites requires further investigation. Alternatively, BBDC 1 could be a product of some internal ice-sheet instability as has been proposed for Heinrich events. However, we cannot assess these mechanisms (e.g. binge/purge oscillations (MacAyeal, 1993), the subglacial outburst-flow model or catastrophic ice shelf breakup model, summarised by Hesse and Khodabakhsh, 2016; Marcott et al., 2011) with the data presented here. 
In contrast, the onset of BBDC $0(\sim 12.7 \mathrm{kyr} B P)$ is coincident, within uncertainty, with the onset of the Younger Dryas stadial. Unlike the BBDC 1 event that, even with age model uncertainties, clearly postdates Heinrich Event 1, the difference between the timing of BBDC 0 and Heinrich Event 0 is not so clear. This rests on the uncertainties regarding the representation of Heinrich Event 0 in previously studied marine records. In earlier Labrador Sea core studies, the onset of Heinrich Event 0 was seen as coincident with the Younger Dryas ( 12.8 kyr BP) (e.g. Andrews et al., 2012, 1995; Hillaire-Marcel et al., 1994; Stoner et al., 1996), but only a small number of these cores in shallower regions show clear evidence of a discrete Heinrich Event 0. Many cores from the deeper north-western Labrador Sea lack a detrital carbonate peak in this late deglacial interval (Andrews et al., 1995; Gibb et al., 2014a; Rashid et al., 2011). Of the few cores with a distinct Heinrich-type layer and adequate radiocarbon dating to constrain the upper and lower limit of the event, the duration of Heinrich 0 is 12.8 to between 12.0-8.7 kyr BP (as summarised by Rashid et al., 2011). Within these poorly constrained age brackets, BBDC 0 from our records would then be coeval with the start of Heinrich Event 0 . However all higher resolution cores present a revised timing of the Heinrich Event 0 onset following the Younger Dryas interval at $11.5 \mathrm{kyr}$ (Hillaire-Marcel and de Vernal, 2008; Jennings et al., 2015; Pearce et al., 2015) (Figures 4 and 7). This suggests that the onset of ice-sheet instabilities of the northern Baffin Bay predates the HO discharge from Hudson Strait recorded mostly in the western Labrador Sea.

Evidence from geochemical data and sedimentation rates points to two modes of detrital deposition during the BBDC 0 event in western Baffin Bay (SL 174). Here, the initial carbonate rich and iceproximal layer is followed by layer of Ti-enriched finer material (Figure S3), followed again by a layer more enriched in carbonate that persisted until the end of the event (Figure 4). While the coarser and more carbonate rich layers were likely transported by iceberg rafting as during BBDC 1 (Figure 2), the fine-grained layer in between requires a different transport mechanism. 


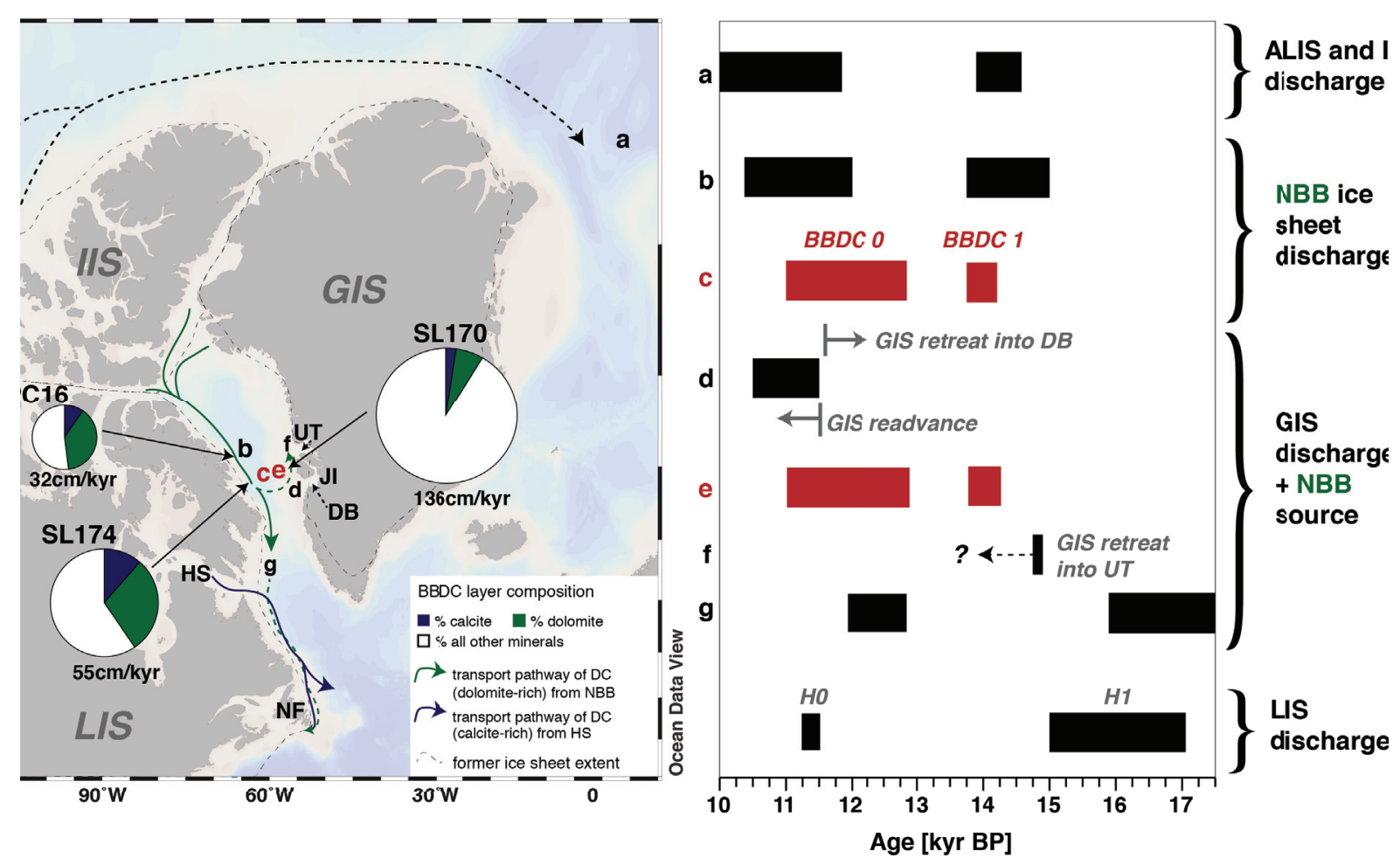

Figure 7. Compilation of the timing of ice-rafted and detrital carbonate events in and around Baffin Bay during the late deglacial period. Map (left) shows the paths of detrital carbonate delivery in the Baffin Bay corridor region. Pie charts indicate the composition of BBDC layers in SL 174 and SL 170 (red, this study) and PC 16 (Simon et al., 2014); pie size is relative to the sedimentation rate during these periods. Letters indicate positions of other cores with detrital layers at various locations. The timing of these events according to their respective age models is shown right. Records used: Fram Strait (a) (Darby and Zimmerman, 2008); NW Baffin Bay (b) (Simon et al., 2014, 2012); SL 174 (c, this study); Disko Bugt Shelf (d) (Jennings et al., 2014); SL 170 (e, this study); Uummannaq Trough (f) (Ò Cofaigh et al., 2013; Sheldon et al., 2016); Labrador Sea (g) (Andrews et al., 2014) and North Atlantic Heinrich Events 1 (Carlson and Clark, 2012) and 0 (Pearce et al., 2015). The comparison of records suggests stochastic behaviour (discharge and iceberg rafting) of the ice sheets surrounding the Baffin Bay. IIS = Innuitian Ice Sheet, LIS = Laurentide Ice Sheet and GIS = Greenland Ice Sheet.

Sediments with such characteristics have been previously attributed to lateral mass flows resulting from rapid basal melting of ocean-terminating glaciers (Aksu and Piper, 1987; Simon et al., 2012). This characteristic composition and sedimentation sequence of BBDC 0 in west Baffin Bay is also seen in the more central PC 16, ruling out this layer as a turbidite. This rapidly deposited sub-layer of BBDC 0 could be seen as a dilution event of the more or less continuous deposition of the detrital carbonate-rich ice-rafted debris from northern Baffin Bay sources. Based on a SedUnMix sediment 
analysis (c.f Andrews and Eberl, 2012; Simon et al., 2014) concluded that at least during the earlier part of the deglaciation, these Ti-rich, finer layers may have been laterally transported from the Uummannaq Trough area (Simon et al., 2014). Although paleoceanographic reconstructions in northwestern Baffin Bay are sparse and do not quite cover the onset of BBDC 0 , the dominance of the Atlantic Water species Cassidulina neoteretis (Perner et al., 2013; Seidenkrantz, 1995) at 12.5 kyr BP in a sediment core located south of the Nares Strait, suggests some influence of the WGC this far north by this time (Knudsen et al., 2008).

Eastward, re-advance of the GIS through Disko Bugt to the shelf edge during the early Younger Dryas and its subsequent retreat around $12.2 \mathrm{kyr}$ BP would be a large source of ice rafted debris. Evidence from sediment cores suggest initial retreat was via calving (Hogan et al., 2016; Jennings et al., 2014; Ó Cofaigh et al., 2013; Rinterknecht et al., 2014), accounting for the elevated sedimentation rates on the Greenland side of Baffin Bay recorded in SL 170 (Figures 3 and 7). This local source would have amplified the effect of enhanced deposition of northern Baffin Bay-sourced detrital carbonate as found in SL 170 and other cores in the Disko Bugt area (Jennings et al., 2014). Whatever the mechanism, the effects of the discharge event from the North American-Arctic ice sheets surrounding the northern portion of Baffin Bay was far-reaching; evidence of a dolomite-rich detrital carbonate component are seen on the Greenland side of Baffin Bay in SL 170 (Figure 7e) and the nearby Disko Bugt shelf (Jennings et al., 2014) (Figure 7d). Furthermore, evidence of a dolomite-rich detrital carbonate layer in the Labrador Sea indicates that these events can travel overspill the Davis Strait (Andrews et al., 2014, 2012, 1995) (Figures 5 and 7g).

The end of BBDC 0 at $\sim 11 \mathrm{kyr}$ BP appears concurrent with ice retreat from the carbonate terranes of northern Baffin Bay (Zreda et al., 1999) and coincides with exposure dates of $\sim 11.1-10.8 \mathrm{kyr}$ BP from the Lancaster Sound area (Ledu et al., 2010). By this time, transport of detrital carbonate from exposure dates indicate that ice retreated across the Assiaat Sill (south of Disko Bugt) $\sim 11 \mathrm{kyr} B P$ and reached the mainland 10 kyr BP (Kelley et al., 2013; Young et al., 2013). In northern Disko Bugt, older exposure ages $\sim 11 \mathrm{kyr}$ BP were found at the head of Vagait Strait, indicating that retreat was somewhat faster in this area (Kelley et al., 2015). Similarly Rinterknecht et al. (2014) dated the 
collapse of the Jakobshavn Isbrae ice stream at $12.2 \pm 0.6 \mathrm{kyr}$ BP. However, correcting for the improper uplift adjustment used, by accounting for the gravitational attraction of water towards ice (Cuzzone et al., 2016; Ullman et al., 2016), would place this collapse at the end of the Younger Dryas. Landward retreat of these ice streams would trap detrital material in fjord areas, exhausting the source of clastic material along this portion of the West Greenland coast to the seafloor at site SL 170.

\section{Conclusions}

Our new radiocarbon-based chronology indicates centennial synchronicity in the deposition of two distinct detrital carbonate layers across Baffin Bay during the last deglaciation and early Holocene $(\sim 17-10 \mathrm{kyr}$ BP). We have determined that these layers represent the previously identified Baffin Bay Detrital Carbonate Events (BBDCs). Using the new chronology, we redefine the timing of these events as occurring between $\sim 14.2-13.7 \mathrm{kyr}$ BP (BBDC 1) and 12.7 - $11 \mathrm{kyr}$ BP (BBDC 0). The onset of BBDC 1 ( 14.2 kyr BP) appears to have lagged Greenland warming and the event occurred completely out of phase with Heinrich Event 1. Iceberg and meltwater discharge from the North American-Arctic ice sheets during the latter part of the Bølling and into the Allerød interstadial implies the presence of significant amounts of icebergs and meltwater, which could have been channelled into the Labrador Sea through the Davis Strait. This finding questions the common assumption that iceberg discharge events caused reductions in Atlantic meridional overturning circulation and cold stadial conditions (Broecker, 1994).

The onset of BBDC $0(\sim 12.7 \mathrm{kyr} \mathrm{BP})$ in the Younger Dryas stadial and its continuation into the Holocene ( 11 kyr BP) suggest that instability of the North American-Arctic ice sheets could have been stochastic and independent of temperature change. This event was far-reaching and evidence of BBDC 0 is found in other cores on the western Greenland margin (Jennings et al., 2014) and the northwest Labrador Sea (Andrews et al., 2012, 1995). New records from the Labrador Sea suggest that BBDC 0 may have pre-dated the major discharge event from the Laurentide Ice Sheet via the Hudson Strait, Heinrich Event 0 (Pearce et al., 2015). The different timing of iceberg discharge events between Baffin Bay and the Labrador Sea therefore adds to the complexity of our understanding of abrupt climate change. Our results also highlight the importance of considering regional 
responses/linkages of ice sheets to/with abrupt climatic changes not only during the last deglacial period, but likely during earlier ice retreat intervals.

\section{Acknowledgements}

We thank the captain and crew of RV Maria S. Merian for support during the expedition MSM09/2 and Hartmut Schulz for help with curation of the sediment cores. The manuscript benefited from comments by Paul Knutz and two anonymous referees of an earlier version and comments from David Piper and an anonymous referee. R. Jackson would also like to thank S. Mulitza for help with the BACON age-modelling. This project was supported by the Deutsche Forschungsgemeinschaft (DFG) through the International Research Training Group "Processes and impacts of climate change in the North Atlantic Ocean and the Canadian Arctic" (IRTG 1904 ArcTrain). A.E. Carlson notes support from the U.S. National Science Foundation Polar Programs (ANS-1418074).

\section{References}

Aksu, A.E., 1983. Holocene and Pleistocene dissolution cycles in deep-sea cores of Baffin Bay and Davis Strait: Palaeoceano-graphic implications. Mar. Geol. 53, 331-348.

Aksu, A.E., Piper, D.J.W., 1987. Late Quaternary sedimentation in Baffin Bay. Can. J. Earth Sci. 24, 1833-1846. doi:10.1139/e87-174

Andrews, J.T., Aksu, A., Kelly, M., Klassen, R., Miller, G.H., Mode, W.N., Mudie, P., 1985. Land/ocean correlations during the last interglacial/glacial transition, Baffin Bay, northwestern North Atlantic: A review. Quat. Sci. Rev. 4, 333-355.

Andrews, J.T., Barber, D.C., Jennings, A.E., Eberl, D.D., Maclean, B., Kirby, M.E., Stoner, J.S., 2012. Varying sediment sources (Hudson Strait, Cumberland Sound, Baffin Bay) to the NW Labrador Sea slope between and during Heinrich events 0 to 4. J. Quat. Sci. 27, 475-484. doi:10.1002/jqs.2535

Andrews, J.T., Eberl, D.D., 2012. Determination of sediment provenance by unmixing the mineralogy of source-area sediments: The "SedUnMix" program. Mar. Geol. 291-294, 24-33. doi:10.1016/j.margeo.2011.10.007

Andrews, J.T., Eberl, D.D., Scott, D., 2011. Surface (sea floor) and near-surface (box cores) sediment mineralogy in Baffin Bay as a key to sediment provenance and ice sheet variations. Can. J. Earth Sci. 48, 1307-1328. doi:10.1139/e11-021

Andrews, J.T., Gibb, O.T., Jennings, A.E., Simon, Q., 2014. Variations in the provenance of sediment from ice sheets surrounding Baffin Bay during MIS 2 and 3 and export to the Labrador Shelf Sea: site HU2008029-0008 Davis Strait. J. Quat. Sci. 29, 3-13. doi:10.1002/jqs.2643

Andrews, J.T., Jennings, A.E., Kerwin, M., Kirby, M., Manley, W., Miller, G.H., Bond, G., MacLean, B., 1995. A Heinrich-like event, H-O (DC-0): Source(s) for detrital carbonate in the North Atlantic during the Younger Dryas Chronozone. Paleoceanography 10, 943-952. 
Andrews, J.T., Kirby, M.E., Aksu, A., Barber, D.C., Messe, D., 1998. Late Quaternary Detrital Carbonate (DC-) layers in Baffin Bay marine sediments $\left(67^{\circ}-74^{\circ} \mathrm{N}\right)$ : Correlation with Heinrich Events in the North Atlantic? Quat. Sci. Rev. 17, 1125-1137.

Balsam, W.L., Deaton, B.C., Damuth, J.E., 1999. Evaluating optical lightness as a proxy for carbonate content in marine sediment cores. Mar. Geol. 161, 141-153. doi:10.1016/S00253227(99)00037-7

Bard, E., Arnold, M., Mangerud, J., Paterne, M., Labeyrie, L., Duprat, J., Mélières, M.-A., Sønstegaard, E., Duplessy, J.-C., 1994. The North Atlantic atmosphere-sea surface 14C gradient during the Younger Dryas climatic event. Earth Planet. Sci. Lett. 126, 275-287. doi:10.1016/0012-821X(94)90112-0

Bard, E., Tuna, T., Fagault, Y., Bonvalot, L., Wacker, L., Fahrni, S., Synal, H.-A., 2015. AixMICADAS, the accelerator mass spectrometer dedicated to $14 \mathrm{C}$ recently installed in Aix-en-Provence, France. Nucl. Instruments Methods Phys. Res. Sect. B Beam Interact. with Mater. Atoms 361, 80-86. doi:10.1016/j.nimb.2015.01.075

Bauer, J.E., Reimers, C.E., Druffel, E.R.M., Williams, P.M., 1995. Isotopic constraints on carbon exchange between deep ocean sediments and sea water. Nature 373, 686-689. doi: $10.1038 / 373686 a 0$

Blaauw, M., 2010. Methods and code for "classical" age-modelling of radiocarbon sequences. Quat. Geochronol. 5, 512-518. doi:10.1016/j.quageo.2010.01.002

Blaauw, M., Christen, J.A., 2011. Flexible paleoclimate age-depth models using an autoregressive gamma process. Bayesian Anal. 6, 457-474.

Bond, G., Broecker, W., Johnsen, S., McManus, J., Labeyrie, L., Jouzel, J., Bonani, G., 1993. Correlations between climate records from North Atlantic sediments and Greenland ice. Nature 365, 143-147. doi:10.1038/365143a0

Bond, G., Showers, W., Chesby, M., Lotti, R., Almasi, P., deMenocal, P., Priore, P., Cullen, H., Hajdas, I., Bonani, G., 1997. A Pervasive Millennial-Scale Cycle in North Atlantic Holocene and Glacial Climates. Science (80-. ). 278, 1257-1266. doi:10.1126/science.278.5341.1257

Broecker, W.S., 1994. Massive iceberg discharges as triggers for global climate change. Nature 372 , 421-424. doi:10.1038/372421a0

Buizert, C., Gkinis, V., Severinghaus, J.P., He, F., Lecavalier, B.S., Kindler, P., Leuenberger, M., Carlson, A.E., Vinther, B., Masson-Delmotte, V., White, J.W.C., Liu, Z., Otto-Bliesner, B., Brook, E.J., 2014. Greenland temperature response to climate forcing during the last deglaciation. Science 345, 1177-80. doi:10.1126/science.1254961

Carlson, A.E., Clark, P.U., 2012. Ice sheet sources of sea level rise and freshwater discharge during the last deglaciation. Rev. Geophys. 50, RG4007. doi:10.1029/2011RG000371

Carlson, A.E., Winsor, K., 2012. Northern Hemisphere ice-sheet responses to past climate warming. Nat. Geosci. 5, 607-613. doi:10.1038/ngeo1528

Channell, J.E.T., Hodell, D.A., Romero, O., Hillaire-Marcel, C., de Vernal, A., Stoner, J.S., Mazaud, A., Röhl, U., 2012. A 750-kyr detrital-layer stratigraphy for the North Atlantic (IODP Sites U1302U1303, Orphan Knoll, Labrador Sea). Earth Planet. Sci. Lett. 317-318, 218-230. doi:10.1016/j.epsl.2011.11.029

Clark, P.U., Shakun, J.D., Baker, P.A., Bartlein, P.J., Brewer, S., Brook, E., Carlson, A.E., Cheng, H., Kaufman, D.S., Liu, Z., Marchitto, T.M., Mix, A.C., Morrill, C., Otto-Bliesner, B.L., Pahnke, K., Russell, J.M., Whitlock, C., Adkins, J.F., Blois, J.L., Clark, J., Colman, S.M., Curry, W.B., Flower, 
B.P., He, F., Johnson, T.C., Lynch-Stieglitz, J., Markgraf, V., McManus, J., Mitrovica, J.X., Moreno, P.I., Williams, J.W., 2012. Global climate evolution during the last deglaciation. Proc. Natl. Acad. Sci. 109, E1134-E1142. doi:10.1073/pnas.1116619109

Coulthard, R.D., Furze, M.F.A., Pieńkowski, A.J., Chantel Nixon, F., England, J.H., 2010. New marine $\triangle \mathrm{R}$ values for Arctic Canada $\boldsymbol{s}^{2}$ Quat. Geochronol. 5, 419-434. doi:10.1016/j.quageo.2010.03.002

Cuzzone, J.K., Clark, P.U., Carlson, A.E., Ullman, D.J., Rinterknecht, V.R., Milne, G.A., Lunkka, J.-P., Wohlfarth, B., Marcott, S.A., Caffee, M., 2016. Final deglaciation of the Scandinavian Ice Sheet and implications for the Holocene global sea-level budget. Earth Planet. Sci. Lett. 448, 34-41. doi:10.1016/j.epsl.2016.05.019

Darby, D.A., Zimmerman, P., 2008. Ice-rafted detritus events in the Arctic during the last glacial interval, and the timing of the Innuitian and Laurentide ice sheet calving events. Polar Res. 27, 114-127. doi:10.1111/j.1751-8369.2008.00057.x

Deschamps, P., Durand, N., Bard, E., Hamelin, B., Camoin, G., Thomas, A.L., Henderson, G.M., Okuno, J., Yokoyama, Y., 2012. Ice-sheet collapse and sea-level rise at the Bølling warming 14,600 years ago. Nature 483, 559-64. doi:10.1038/nature10902

Dyke, A.S., Andrews, J.T., Clark, P.U., England, J.H., Miller, G.H., Shaw, J., Veillette, J.J., 2002. The Laurentide and Innuitian ice sheets during the Last Glacial Maximum. Quat. Sci. Rev. 21, 9-31. doi:10.1016/S0277-3791(01)00095-6

England, J., Atkinson, N., Bednarski, J., Dyke, A.S., Hodgson, D.A., Ó Cofaigh, C., 2006. The Innuitian Ice Sheet: configuration, dynamics and chronology. Quat. Sci. Rev. 25, 689-703. doi:10.1016/j.quascirev.2005.08.007

Gibb, O.T., 2014a. Paleohydrography of Baffin Bay, Davis Strait, and the northwest Labrador Sea during the last climatic cycle. UNIVERSITÉ DU QUÉBEC À MONTRÉAL.

Gibb, O.T., Hillaire-Marcel, C., de Vernal, A., 2014. Oceanographic regimes in the northwest Labrador Sea since Marine Isotope Stage 3 based on dinocyst and stable isotope proxy records. Quat. Sci. Rev. doi:10.1016/j.quascirev.2013.12.010

Gibb, O.T., Steinhauer, S., Frechette, B., de Vernal, A., Hillaire-Marcel, C., 2015. Diachronous evolution of sea surface conditions in the Labrador Sea and Baffin Bay since the last deglaciation. The Holocene 25, 1882-1897. doi:10.1177/0959683615591352

Heinrich, H., 1988. Origin and consequences of cyclic ice rafting in the Northeast Atlantic Ocean during the past 130,000 years. Quat. Res. 29, 142-152. doi:10.1016/0033-5894(88)90057-9

Hemming, S.R., 2004. Heinrich events: Massive late Pleistocene detritus layers of the North Atlantic and their global climate imprint. Rev. Geophys. 42, RG1005. doi:10.1029/2003RG000128

Hesse, R., Khodabakhsh, S., 2016. Anatomy of Labrador Sea Heinrich layers. Mar. Geol. doi:10.1016/j.margeo.2016.05.019

Hillaire-Marcel, C., de Vernal, A., 2008. Stable isotope clue to episodic sea ice formation in the glacial North Atlantic, Earth and Planetary Science Letters.

Hillaire-Marcel, C., Vernal, A. de, Bilodeau, G., Wu, G., 1994. Isotope stratigraphy, sedimentation rates, deep circulation, and carbonate events in the Labrador Sea during the last $\sim 200 \mathrm{ka}$. Can. J. Earth Sci. 31, 63-89. doi:10.1139/e94-007

Hiscott, R., Aksu, A., Nielsen, O., 1989. Provenance and dispersal patterns, Pliocene-Pleistocene section at site 645, Baffin Bay. Proc. Ocean Drill. Progr.

Hodell, D.A., Channell, J.E.T., Curtis, J.H., Romero, O.E., Röhl, U., 2008. Onset of "Hudson Strait" 
Heinrich events in the eastern North Atlantic at the end of the middle Pleistocene transition ( 640 ka)? Paleoceanography 23, n/a-n/a. doi:10.1029/2008PA001591

Hoffman, J.S., Carlson, A.E., Winsor, K., Klinkhammer, G.P., LeGrande, A.N., Andrews, J.T., Strasser, J.C., 2012. Linking the 8.2 ka event and its freshwater forcing in the Labrador Sea. Geophys. Res. Lett. 39. doi:10.1029/2012GL053047

Hogan, K.A., Jennings, A.E., Dowdeswell, J.A., Hiemstra, J.F., 2016. Deglaciation of a major palaeoice stream in Disko Trough, West Greenland. Quat. Sci. Rev. 147, 5-26. doi:10.1016/j.quascirev.2016.01.018

Jennings, A., Andrews, J., Pearce, C., Wilson, L., Ólfasdótttir, S., 2015. Detrital carbonate peaks on the Labrador shelf, a 13-7ka template for freshwater forcing from the Hudson Strait outlet of the Laurentide Ice Sheet into the subpolar gyre. Quat. Sci. Rev. 107, 62-80. doi:10.1016/j.quascirev.2014.10.022

Jennings, A., Sheldon, C., Cronin, T., Francus, P., Stoner, J., Andrews, J., 2011. The Holocene History of Nares Strait: Transition from Glacial Bay to Arctic-Atlantic Throughflow. Oceanography 24, 26-41. doi:10.5670/oceanog.2011.52

Jennings, A.E., Hald, M., Smith, M., Andrews, J.T., 2006. Freshwater forcing from the Greenland Ice Sheet during the Younger Dryas: evidence from southeastern Greenland shelf cores. Quat. Sci. Rev. 25, 282-298.

Jennings, A.E., Walton, M.E., Ó Cofaigh, C., Kilfeather, A., Andrews, J.T., Ortiz, J.D., De Vernal, A., Dowdeswell, J.A., 2014. Paleoenvironments during Younger Dryas-Early Holocene retreat of the Greenland Ice Sheet from outer Disko Trough, central west Greenland. J. Quat. Sci. 29, 27-40. doi:10.1002/jqs.2652

Kelley, S.E., Briner, J.P., Young, N.E., 2013. Rapid ice retreat in Disko Bugt supported by $10 B e$ dating of the last recession of the western Greenland Ice Sheet. Quat. Sci. Rev. 82, 13-22. doi:10.1016/j.quascirev.2013.09.018

Kelley, S.E., Briner, J.P., Zimmerman, S.R.H., 2015. The influence of ice marginal setting on early Holocene retreat rates in central West Greenland. J. Quat. Sci. 30, 271-280. doi:10.1002/jqs.2778

Knudsen, K.-L., Stabell, B., Seidenkrantz, M.-S., Eiriksson, J., Blake Jr, W., 2008. Deglacial and Holocene conditions in northernmost Baffin Bay: sediments, foraminifera, diatoms and stable isotopes. Boreas 37, 346-376. doi:10.1111/j.1502-3885.2008.00035.x

Knutz, P.C., Sicre, M.-A., Ebbesen, H., Christiansen, S., Kuijpers, A., 2011. Multiple-stage deglacial retreat of the southern Greenland Ice Sheet linked with Irminger Current warm water transport. Paleoceanography 26, n/a-n/a. doi:10.1029/2010PA002053

Kucera, M., Rhein, M., Gohl, K., 2014. Oceanography and geodynamics in the NW Atlantic and the Baffin Bay - Cruise No. MSM09 - July 23 - October 29, 2008 - Bremen (Germany) - Ponta Delgada (Azores). doi:10.2312/cr_msm09.

Ledu, D., Rochon, A., de Vernal, A., St-Onge, G., 2010. Holocene paleoceanography of the northwest passage, Canadian Arctic Archipelago. Quat. Sci. Rev. 29, 3468-3488. doi:10.1016/j.quascirev.2010.06.018

Levac, E., Vernal, A. De, Blake Jr, W., 2001. Sea-surface conditions in northernmost Baffin Bay during the Holocene: palynological evidence. J. Quat. Sci. 16, 353-363. doi:10.1002/jqs.614

Li, G., Piper, D.J.W., Calvin Campbell, D., 2011. The Quaternary Lancaster Sound trough-mouth fan, NW Baffin Bay. J. Quat. Sci. 26, 511-522. doi:10.1002/jqs.1479

Liu, J., Milne, G.A., Kopp, R.E., Clark, P.U., Shennan, I., 2015. Sea-level constraints on the amplitude 
Liu, Z., Otto-Bliesner, B.L., He, F., Brady, E.C., Tomas, R., Clark, P.U., Carlson, A.E., Lynch-Stieglitz, J., Curry, W., Brook, E., Erickson, D., Jacob, R., Kutzbach, J., Cheng, J., 2009. Transient simulation of last deglaciation with a new mechanism for Bolling-Allerod warming. Science 325, 310-4. doi:10.1126/science.1171041

Lloyd, J., Moros, M., Perner, K., Telford, R.J., Kuijpers, A., Jansen, E., McCarthy, D., 2011. A 100 yr record of ocean temperature control on the stability of Jakobshavn Isbrae, West Greenland. Geology 39, 867-870. doi:10.1130/G32076.1

Lund, D.C., Mix, A.C., Southon, J., 2011. Increased ventilation age of the deep northeast Pacific Ocean during the last deglaciation. Nat. Geosci. 4, 771-774. doi:10.1038/ngeo1272

MacAyeal, D.R., 1993. Binge/purge oscillations of the Laurentide Ice Sheet as a cause of the North Atlantic's Heinrich events. Paleoceanography 8, 775-784. doi:10.1029/93PA02200

Marcott, S.A., Clark, P.U., Padman, L., Klinkhammer, G.P., Springer, S.R., Liu, Z., Otto-Bliesner, B.L., Carlson, A.E., Ungerer, A., Padman, J., He, F., Cheng, J., Schmittner, A., 2011. Ice-shelf collapse from subsurface warming as a trigger for Heinrich events. Proc. Natl. Acad. Sci. U. S. A. 108, 13415-9. doi:10.1073/pnas.1104772108

McManus, J.F., Francois, R., Gherardi, J.-M., Keigwin, L.D., Brown-Leger, S., 2004. Collapse and rapid resumption of Atlantic meridional circulation linked to deglacial climate changes. Nature 428, 834-7. doi:10.1038/nature02494

Ó Cofaigh, C., Andrews, J.T., Jennings, A.E., Dowdeswell, J.A., Hogan, K.A., Kilfeather, A.A., Sheldon, C., 2013a. Glacimarine lithofacies, provenance and depositional processes on a West Greenland trough-mouth fan. J. Quat. Sci. 28, 13-26. doi:10.1002/jqs.2569

Ò Cofaigh, C., Dowdeswell, J.A., Jennings, A.E., Hogan, K.A., Kilfeather, A., Hiemstra, J.F., Noormets, R., Evans, J., McCarthy, D.J., Andrews, J.T., Lloyd, J.M., Moros, M., 2013. An extensive and dynamic ice sheet on the West Greenland shelf during the last glacial cycle. Geology 41, 219-222. doi:10.1130/G33759.1

Obbink, E.A., Carlson, A.E., Klinkhammer, G.P., 2010. Eastern North American freshwater discharge during the Bolling-Allerod warm periods. Geology 38, 171-174. doi:10.1130/G30389.1

Ouellet-Bernier, M.-M., de Vernal, A., Hillaire-Marcel, C., Moros, M., 2014. Paleoceanographic changes in the Disko Bugt area, West Greenland, during the Holocene. The Holocene 24, 15731583. doi:10.1177/0959683614544060

Pearce, C., Andrews, J.T., Bouloubassi, I., Hillaire-Marcel, C., Jennings, A.E., Olsen, J., Kuijpers, A., Seidenkrantz, M.-S., 2015. Heinrich 0 on the east Canadian margin: Source, distribution, and timing. Paleoceanography 30, 1613-1624. doi:10.1002/2015PA002884

Pearce, C., Seidenkrantz, M.-S., Kuijpers, A., Massé, G., Reynisson, N.F., Kristiansen, S.M., 2013. Ocean lead at the termination of the Younger Dryas cold spell. Nat. Commun. 4, 1664. doi:10.1038/ncomms2686

Perner, K., Moros, M., Jennings, A., Lloyd, J., Knudsen, K., 2013. Holocene palaeoceanographic evolution off West Greenland. The Holocene 23, 374-387. doi:10.1177/0959683612460785

Perner, K., Moros, M., Lloyd, J.M., Kuijpers, A., Telford, R.J., Harff, J., 2011. Centennial scale benthic foraminiferal record of late Holocene oceanographic variability in Disko Bugt, West Greenland. Quat. Sci. Rev. 30, 2815-2826.

Rashid, H., Piper, D.J.W., Flower, B.P., 2011. The Role of Hudson Strait Outlet in Younger Dryas Sedimentation in the Labrador Sea, in: Abrupt Climate Change: Mechanisms, Patterns, and Impacts. American Geophysical Union, pp. 93-110. doi:10.1029/2010GM001011 
Reimer, P., 2013. IntCal13 and Marine13 Radiocarbon Age Calibration Curves 0-50,000 Years cal BP. Radiocarbon 55, 1869-1887. doi:10.2458/azu_js_rc.55.16947

Rinterknecht, V., Jomelli, V., Brunstein, D., Favier, V., Masson-Delmotte, V., Bourles, D., Leanni, L., Schlappy, R., 2014. Unstable ice stream in Greenland during the Younger Dryas cold event. Geology 42, 759-762. doi:10.1130/G35929.1

Seidenkrantz, M.-S., 1995. Cassidulina teretis Tappan and Cassidulina neoteretis new species (Foraminifera): stratigraphic markers for deep sea and outer shelf areas. J. Micropalaeontology 14, 145-157. doi:10.1144/jm.14.2.145

Shakun, J.D., Carlson, A.E., 2010. A global perspective on Last Glacial Maximum to Holocene climate change. Quat. Sci. Rev. 29, 1801-1816. doi:10.1016/j.quascirev.2010.03.016

Sheldon, C., Jennings, A., Andrews, J.T., Hogan, K., Dowdeswell, J.A., Seidenkrantz, M.-S., 2016. Ice stream retreat following the LGM and onset of the west Greenland current in Uummannaq Trough, west Greenland. Quat. Sci. Rev. 147, 27-46. doi:10.1016/j.quascirev.2016.01.019

Simon, Q., Hillaire-Marcel, C., St-Onge, G., Andrews, J.T., 2014. North-eastern Laurentide, western Greenland and southern Innuitian ice stream dynamics during the last glacial cycle. J. Quat. Sci. 29, 14-26. doi:10.1002/jqs.2648

Simon, Q., St-Onge, G., Hillaire-Marcel, C., 2012. Late Quaternary chronostratigraphic framework of deep Baffin Bay glaciomarine sediments from high-resolution paleomagnetic data. Geochemistry, Geophys. Geosystems 13. doi:10.1029/2012GC004272

Simon, Q., Thouveny, N., Bourlès, D.L., Nuttin, L., Hillaire-Marcel, C., St-Onge, G., 2016. Authigenic $10 \mathrm{Be} / 9 \mathrm{Be}$ ratios and 10Be-fluxes (230Thxs-normalized) in central Baffin Bay sediments during the last glacial cycle: Paleoenvironmental implications. Quat. Sci. Rev. 140, 142-162. doi:10.1016/j.quascirev.2016.03.027

Stoner, J.S., Channell, J.E.T., Hillaire-Marcel, C., 1996. The magnetic signature of rapidly deposited detrital layers from the Deep Labrador Sea: Relationship to North Atlantic Heinrich layers. Paleoceanography 11, 309-325. doi:10.1029/96PA00583

Tang, C.C.., Ross, C.K., Yao, T., Petrie, B., DeTracey, B.M., Dunlap, E., 2004. The circulation, water masses and sea-ice of Baffin Bay. Prog. Oceanogr. 63, 183-228.

Tarasov, L., Dyke, A.S., Neal, R.M., Peltier, W.R., 2012. A data-calibrated distribution of deglacial chronologies for the North American ice complex from glaciological modeling. Earth Planet. Sci. Lett. 315-316, 30-40. doi:10.1016/j.epsl.2011.09.010

Thiagarajan, N., Subhas, A. V, Southon, J.R., Eiler, J.M., Adkins, J.F., 2014. Abrupt pre-BøllingAllerød warming and circulation changes in the deep ocean. Nature 511, 75-8. doi:10.1038/nature13472

Thornalley, D.J.R., Barker, S., Broecker, W.S., Elderfield, H., McCave, I.N., 2011. The deglacial evolution of North Atlantic deep convection. Science 331, 202-5. doi:10.1126/science.1196812

Ullman, D.J., Carlson, A.E., Hostetler, S.W., Clark, P.U., Cuzzone, J., Milne, G.A., Winsor, K., Caffee, M., 2016. Final Laurentide ice-sheet deglaciation and Holocene climate-sea level change. Quat. Sci. Rev. 152, 49-59. doi:10.1016/j.quascirev.2016.09.014

Wacker, L., Lippold, J., Molnár, M., Schulz, H., 2013. Towards radiocarbon dating of single foraminifera with a gas ion source. Nucl. Instruments Methods Phys. Res. Sect. B Beam Interact. with Mater. Atoms 294, 307-310. doi:10.1016/j.nimb.2012.08.038

Winsor, K., Carlson, A.E., Klinkhammer, G.P., Stoner, J.S., Hatfield, R.G., 2012. Evolution of the northeast Labrador Sea during the last interglaciation. Geochemistry, Geophys. Geosystems 13, n/a-n/a. doi:10.1029/2012GC004263 
Wu, G., Hillaire-Marcel, C., 1994. Accelerator mass spectrometry radiocarbon stratigraphies in deep Labrador Sea cores: paleoceanographic implications. Can. J. Earth Sci. 31, 38-47.

Young, N.E., Briner, J.P., Rood, D.H., Finkel, R.C., Corbett, L.B., Bierman, P.R., 2013. Age of the Fjord Stade moraines in the Disko Bugt region, western Greenland, and the 9.3 and $8.2 \mathrm{ka}$ cooling events. Quat. Sci. Rev. 60, 76-90. doi:10.1016/j.quascirev.2012.09.028

Zreda, M., England, J., Phillips, F., Elmore, D., Sharma, P., 1999. Unblocking of the Nares Strait by Greenland and Ellesmere ice-sheet retreat 10,000 years ago. Nature 398, 139-142. doi:10.1038/18197 